\title{
The Nature and Articulation of Ethical Codes on Tailings Management in South Africa
}

\author{
${ }^{1}$ Tobius Thobile Poswa and ${ }^{2}$ Theophilus Clavell Davies \\ ${ }^{1}$ Department of Environmental Health, Faculty of Natural Sciences, Mangosuthu University \\ of Technology, 511 Mangosuthu Highway, Umlazi 4031, KwaZulu Natal, South Africa \\ ${ }^{2}$ Department of Geology, University of Nigeria, Nsukka, Nsukka Road, 410001 Nsukka, \\ Nigeria \\ Corresponding author e-mail: theophilus.davies@unn.edu.ng
}

\begin{abstract}
It is well recognised that the mining industry in South Africa is highly rated for its substantial contribution to the country's economic growth, including employment and infrastructural development. It is also known that mining and ore processing activities potentially pose a severe threat to public health and environmental well-being, in the way operations are carried out, mine wastes are disposed of (in dumps), local communities are relocated, mine management and the mining community in general, perceive established environmental standards and etiquette. This paper examines ethical practices and norms in the South African mining industry, with particular reference to the management of tailings dams. We analyse the modes of articulation of the country's regulatory instruments for tailings management, and review the corporate social responsibility (CSR) approach of leading mining companies. Despite decades of research and resulting recommendations on tailings management, it is concluded that current legislations are largely ineffective, level of adherence by mine management and the mining community, low, and mechanisms for compliance monitoring, weak. New perspectives on legislative issues for unsolved problems in tailings handling are put forward, and directions for future research, indicated.
\end{abstract}

Keywords: Mine tailings, ethics, legislations, corporate social responsibility, policy research, South Africa

\section{Research highlights:}

(i) Evolution of South Africa's regulatory codes and the ethical position, as well as the behaviour of major mining companies in the area of tailings management, reviewed;

(ii) Systematic approach to addressing the mammoth challenges posed in operation of tailings dams, prescribed;

(iii) Demonstration made of how carefully formulated guidelines and revised regulations for safety management can be successfully applied;

(iv) Areas of tailings management that need more research attention (e.g. their useful application), are brought to the fore, and the way forward, charted.

\section{INTRODUCTION}

\subsection{Background and problem statement}

The Republic of South Africa remains one of the top 5 mining countries of the world (Hydralok, 2016; World Bank, 2016). Cronje et al. (2013) acknowledge mining companies' contribution towards improved social development, in providing jobs, paying taxes, building 
an industrial base, enhancing efficiency, earning foreign exchange and transferring technology. On the other hand, some of these companies have been linked to a number of blatant public maleficient practices, including interference in sovereign affairs, deepening disparities in wealth, poor labour conditions, corruption, transfer pricing, and disrespect of human rights (Eweje, 2005; Cronje et al.; 2013; Diale, 2014; Saperstein, 2014). But some (e.g., Manungufala et al., 2005; Schonfeld, 2014; Wright et al., 2014; Lèbre and Corder, 2015) consider the most worrying aspect of present day mining in South Africa to be the ethics of *tailings handling and other mine waste disposal practices; and the impact these have on the health of surrounding communities and the environment as a whole, by way of pollution incidents, safety failings and reduction in the amount of space available for lowcost housing projects.

*Footnote: In this paper, the term 'tailings' is used interchangeably with the broader term 'mine residue deposits' (MRDs), which is used in South Africa (RSA DME, 2000) to denote dumps, heaps, piles, fillings or tailings dams consisting of mine residue, which usually project above the natural ground surface, but may occupy the space of a pre-existing excavation.

Metalliferous mines in the country produce a substantial volume of mine waste. In 2007, Rademeyer estimated that approximately 12,000 ha of land is sterilised by 150 mine residue deposits (MRDs) in the Gauteng Province alone. Only a small percentage of the total waste generated can potentially be backfilled into worked-out areas underground, and the bulk of it is deposited in large surface impoundments or tailings dams. According to RSA DEA (2012), many of these dams are unlined and unvegetated (Fig. 1). They constitute the largest single source of pollution of the soil, water and air environments in South Africa, including breakdowns in nutrient cycling (See Section 3, this article). Their improper handling can cause the emission of extensive dust, as well as acidification and salinisation of soils. The quantitative prediction and integration of these impacts is difficult to address, and the impacts costly to manage and remedy.

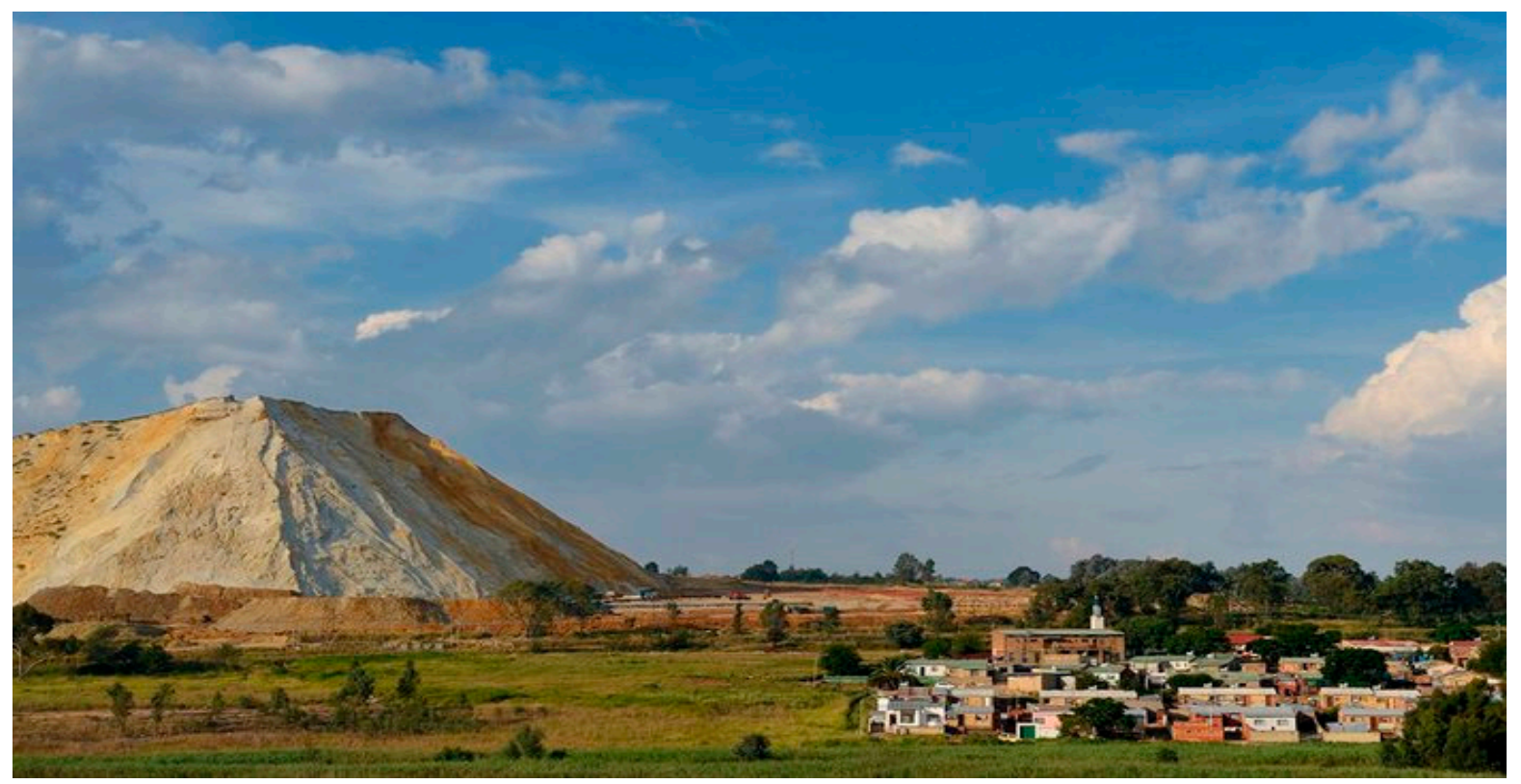

Fig. 1. Johannesburg's Soweto Riverlea neighbourhood in the shadow of a gold mine slag heap. Photograph: Alamy, 2015. Source:

http://www.theguardian.com/cities/2015/jul/06/radioactive-city-how-johannesburgstownships-are-paying-for-its-mining-past (accessed 26.03.16). 
Since the dawn of the anti-apartheid era, a plethora of codes and statements of corporate social responsibility (CSR) have come into being. New constitutional reforms have been introduced, and review of environmental and mining laws undertaken. In spite of these efforts, vestiges of exploitative colonial mining laws appear to be still firmly entrenched in the new legislations, and a number of other deficiencies remain. There are too many loopholes. Strategies for effectively administering, monitoring and enforcing the new laws and policies are still in need of review.

Specific guidelines are not provided for assessment of the sustainability and/or rehabilitation success. In the realm of tailings management proper, disposal practices are still not strictly regulated, and current applicable guidelines for the planning and environmental management of disposal facilities are lax, are not strictly enforced, or are overruled. An overview of their contents and soundness (of guidelines documents), let alone their impact, is missing.

The present attempt provides a closer examination of the nature of existing legislations and codes of corporate practice in tailings management in South Africa, and reviews their mode of articulation. We identify areas in cumulative tailings management legislations that need clarification or further development; and go on to proffer credible strategies for revisitation and revision of the new complementary regulations, so that they meet constitutional requirements, and better align with sound environmental principles. Tangible measures for compliance monitoring are recommended that would help greatly in enhancing the sustainable livelihoods of mining communities and the public.

\subsection{Methodology}

An exploratory approach was adopted in a comprehensive literature search and focus group discussions, to assess the ethics of effective tailings management in South Africa. Firstly, the characteristics, contents and significance of existing national codes of conduct are established. Findings on the current state of tailings management in the country are then corroborated with the provision of brief overviews of critical challenges and an analysis of issues relating to CSR, sustainable development, health and safety, and engagement between communities and mine operators.

We then go on to review the relationship between CSR and codes of conduct, defined for this purpose as written guidelines, recommendations or rules issued by the South African Government, in order to enhance corporate responsibility. Three case studies are appended to illustrate some of the technical, socio-economic and governance challenges faced by industry and regulators in managing the negative impacts derived from improper mine waste disposal practices.

There exists a large volume of documentation relating to all aspects of design, construction, operation and closure of tailings facilities in the form of manuals, technical papers, conference proceedings and textbooks (e.g., See Anglo, 2005); and only a cursory reference is made in this review to the quality of tailings dam design and construction, and the engineering properties and composition of tailings.

We conclude by assessing future trends and charting policy options through the submission of pertinent imperatives. 


\subsection{Main observations and findings}

The study shows that South Africa has made significant progress in directing legal and policy frameworks to address the ethics of tailings disposal. However, areas of vulnerabilities in the current system are shown to still exist; and areas where alignment of the ethics of tailings management by mining companies with the government's current legislations (on tailings handling), is incomplete. There are instances where existing legislations have not provided full justice to communities suffering from socio-economic and health problems due to their exposure to tailings. Articulation of regulations on tailings management has not protected the rights of women in mining as communities or as workers.

As one goes through the paper, it is clear to see that low levels of accountability, transparency and commitment to all aspects related to CSR and sustainable development still persist in many aspects of tailings management in the country.

A number of large mining institutions including foreign consortiums, have drafted their own corporate codes of conduct, but the status of these codes is unclear, and their operationalisation not efficient enough to address the regulatory challenges taking place globally. It is clear from this study that many large mining companies use CSR politically to prevent the introduction of legally enforceable tailings disposal control measures which have a proven record of effectiveness in other top mining countries such as Australia and Canada.

Examples are provided that show concurrence with Fooks et als.' (2013) observation that the mining company's interest in the practice (of CSR) resides largely in its potential to promote policy outcomes that work against public welfare. Possible impediments to mar translation of new research findings and policy initiatives into effective interventions are identified, and ways of obviating them are recommended.

\section{Current Status of Tailings Management in South Africa}

\subsection{Stakeholders and expectations}

Key stakeholders in tailings management in South Africa include:

- The Government;

- Mine management;

- Holders of prospecting or mining rights;

- Mine employees;

- Shareholders;

- Regulators;

- The affected community, which include the landowners, local authorities, business and service providers, community groups and NGOs (Martin et al., 2002; Swart, 2003).

There are some minimum expectations from each one of these stakeholder groups in achieving objectives in the drive towards attaining good management practices. A comprehensive tailings stewardship regime should include the protection of human health and a demonstration of a corporate commitment to social responsibility. Codes of practice should be crafted to engender the need for disposal practices to fall within the constraints of the law. 
To avoid the manifestation of undue risks and ensure the optimisation of resource exploitation, Snyman and Brent (2006) propose that owners of mines and practitioners of mine residue disposal must conduct disposal practices in accordance with fundamental safety and environmental objectives, and principles as given in a set of performance criteria.

\subsection{Handling methods and policies}

Reichardt (2012) has looked at the scientific factors that drove the evolution of mine waste management and rehabilitation techniques in South Africa, and sets out political, social and financial factors that influenced how this was turned into practice in the field. He (Reichardt, 2012) also considers the role of personalities and the organisational constraints within which they operated in implementing these techniques.

Present methods for the transport, deposition and storage of tailings in South Africa still use conventional techniques which are based on moving large volumes of very wet, low-density slurries (Fig. 2). This approach involves the use of large volumes of water and can have negative consequences, in that much of the water is often lost during the operation (Vermeulen, 2001; Snyman and Brent, 2006). Another important issue associated with the storage of fluid residue, concerns the environmental impacts associated with acid mine drainage (AMD) and land sterilisation.

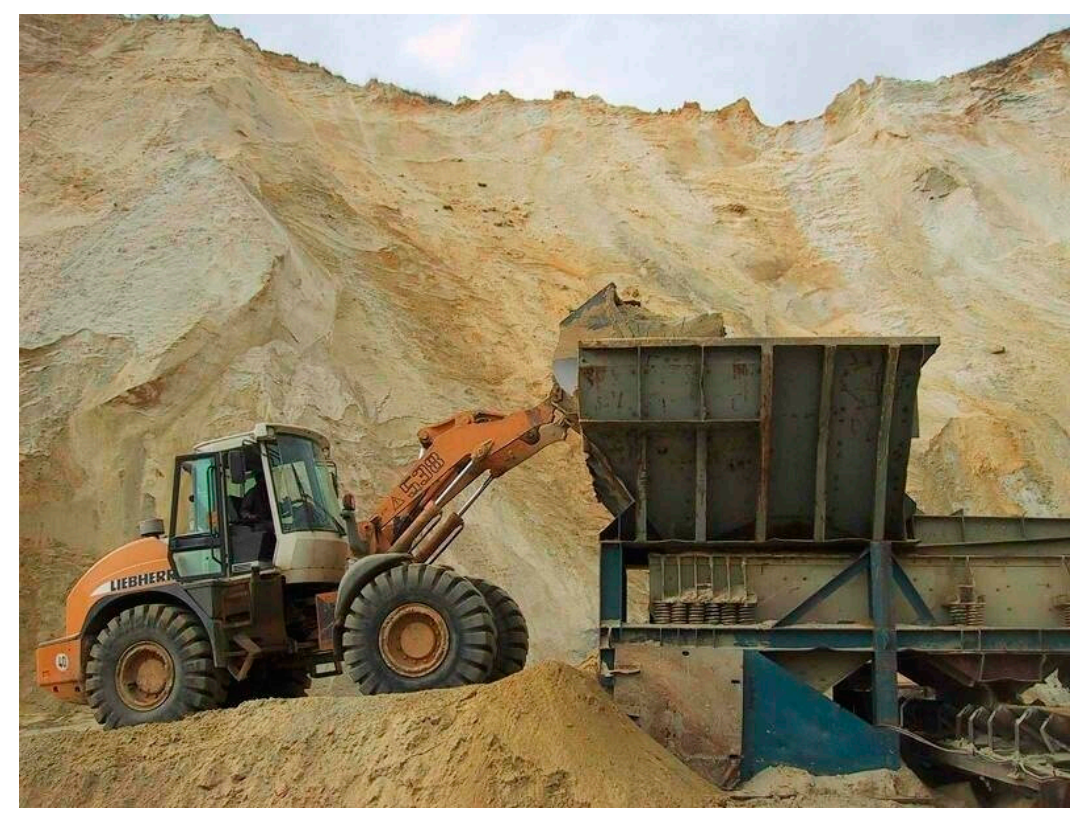

Fig. 2. Gold tailings dam, Johannesburg, South Africa. Credit: EXTRACTEX, 2016. Source: http://www.extrac-tec.com/wp-content/gallery/mining-application/4gold-tailings_sa02.jpg (accessed 26.03.16).

Although significant progress has been made in shifting policy frameworks to ensure responsible and effective stewardship of tailings facilities, loopholes in the current management systems still remain; for example, in policies relating to engineering design and construction of dams, and installation of water storage facilities. Existing standards and guidelines documents do not contain articles that specifically prescribe how these constructions should be done in order to obviate negative environmental impacts including health and safety concerns; but place more focus on the need for management throughout the life cycle of the facilities. The guidelines only require that the facilities be managed by 
appropriately qualified persons, often professional engineers, over their entire life cycle (SABS, 1998).

In the prescription of project management models for the development of new tailings facilities, the guidelines do not even provide a holistic approach for integrating the requirements of the environmental impact assessment (EIA) legislation and the requirements of the South African Bureau of Standards (SABS) Code of Practice (SABS, 1998) during the various project life cycle phases in order to optimise the overall implementation process (Snyman and Brent, 2006).

\section{Social and environmental health issues of tailings dams management: the plight of womenfolk}

Cronje et al. (2013) have listed the social factors that precipitate health disasters in communities associated with management of South Africa's tailings dams. These include poverty, unemployment, poor housing and infrastructure, prostitution and a high influx of unaccompanied migrant labour. In many instances, women bear the brunt of these maladies. Available jobs are given without cognisance of any gender balance.

It is a misconception that local communities are against mining. A direct quote from Mannak (2012) summarises the existing situation quite well: "People in South Africa are desperate for jobs and appreciate what mining can do for them financially. They are however worried about a lack of information, not knowing what their rights are, loss of land, safety of their children, water pollution and their health - among other things."

Major health-related issues among workers and residents brought directly or indirectly by poor tailings handling include exposure to a toxic mix of radioactive elements (Fig. 3), arsenic and heavy metals, loss of biodiversity, impairment of ecosystem services, contributions to ozone depletion and global warming. Harmful particulate matter in the air may result in respiratory illnesses. 


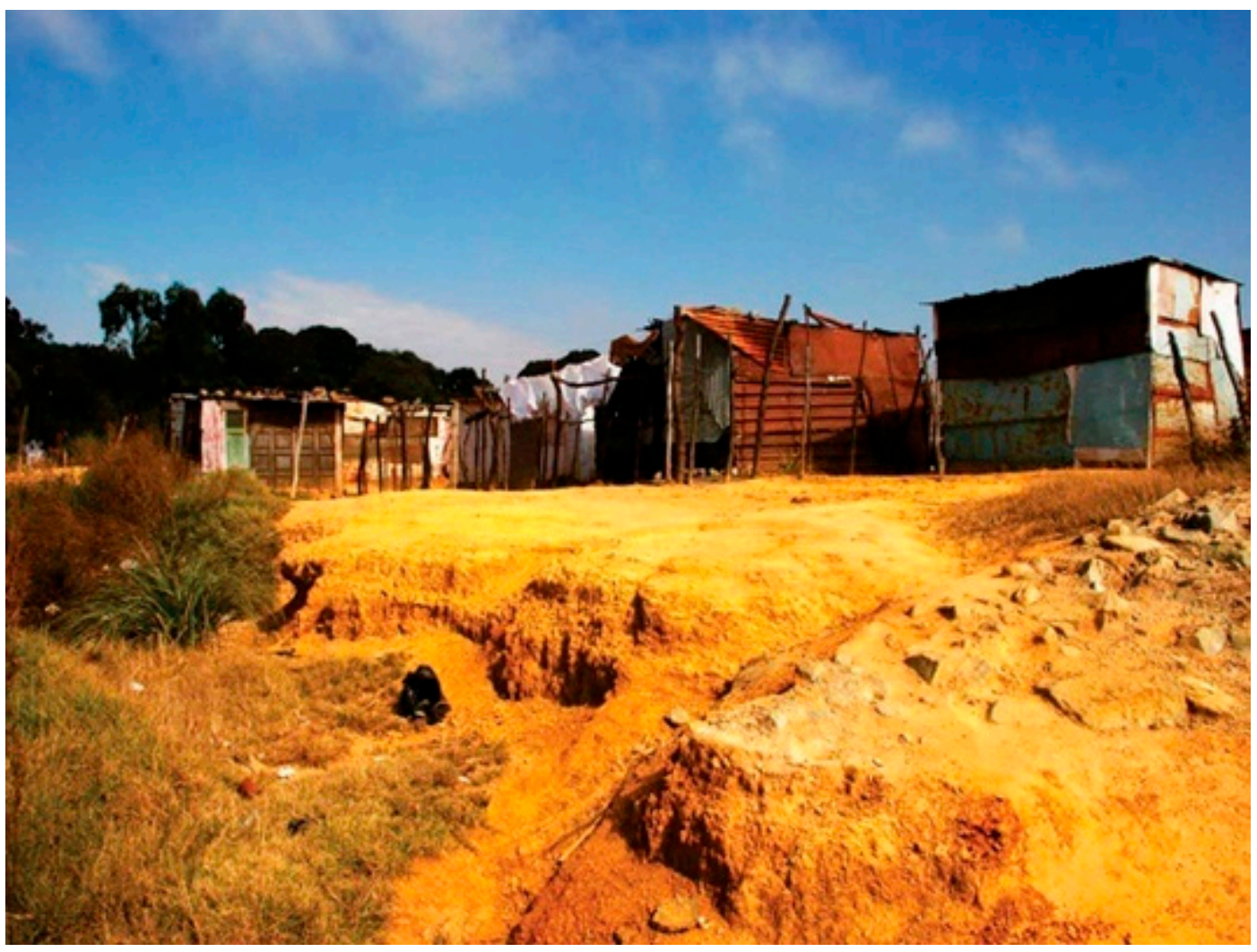

Fig. 3. Mining communities in the Witwatersrand goldfields are often built near, or on top of, tailings piles that contain uranium dust. Credit: Stephan du Toit, 2011. Source: http://www.earthmagazine.org/article/all-glitters-acid-mine-drainage-toxic-legacy-goldmining-south-africa (accessed 26.03.16).

Tailings facilities at abandoned and old mine sites cause water pollution and AMD. Contamination of both ground- and surface water deprives subsistence farmers and large agricultural businesses of water. Cattle and grazing land is affected, depriving communities of an income. A review of these factors by Cronje et al. (2013) led to the conclusion that " ... communities need to be 'fenced in' in terms of health disaster management instead of being excluded".

Women often make up more than 50 percent of a community and form an integral part of the country's land owners (Mcguire, 2003). They are thus more susceptible to the social and environmental health impacts of improper tailings management. The majority of geophagists (people who deliberately, or sometimes inadvertently consume soil) are women. As is now well established, soil around tailings dams often carry a large burden of toxic metals and other contaminants (Fig. 3; Davies and Mundalamo, 2010). These are exactly why the question of inclusivity (See Section 7, this article) is so important for women. Indeed, as McGuire (2003) points out, consultation on the environmental impacts of mining needs to be gender specific to encourage women to discuss issues which pertain to their roles in the provision of health care, education, food security and cultural activities (ceremony) (See Section 7, this article). 


\section{Relevant legislations and modes of articulation}

Mining activities constitute one of the listed activities that should be regulated to give effect to the environmental rights provided in the South African Constitution. As a result of the new legislations and older, but still applicable regulations, a range of applications had to be prepared and submitted to different governmental organisations prior to implementing a new tailings disposal plan.

The principal South African legislations that are currently applicable to tailings dam management include:

I. The Constitution of the Republic of South Africa Act No. 108 of 1996 (CRSA);

II. The Mineral and Petroleum Resources Development Act No. 28 of 2002 (MPRDA);

III. The Code of Practice for Mine Residue Deposits (CPMRD);

IV. The National Environmental Management Act No. 107 of 1998 (NEMA);

V. The National Water Act No. 36 of 1998 (NWA);

VI. The Minerals Act No. 50 of 1991;

VII. The National Environmental Management: Waste Act No. 59 of 2008 (NEMWA);

VIII. The National Environmental Management: Air Quality Act 39 of 2004 (NEMAQA);

IX. The Mine Health and Safety Act 29 of 1996 (MHSA);

X. The Radioactive Waste Management Policy and Strategy for the Republic of South Africa (RWMPS).

A cursory look at these legislations reveals loop-holes, as the ensuing discussion would show. The circumstances where a specific legislation should be applied (re: in tailings management) and the mode of its articulation, remain unclear. Although the legislations are imbued with human values and judgements, ethics seldom forms a part of the entire implementation and monitoring chain. Mine management principles are often below policy and political implications, and there is often a lack of understanding of the interrelationships between the different regulations, and the involvement of the different government departments.

\subsection{The Constitution of the Republic of South Africa Act No. 108 of 1996}

The Constitution of the Republic of South Africa Act No. 108 (of 1996a) (several amendments thereafter), Section 24, provides inter alia, “ ... that everyone has the right to an environment that is not harmful to health and well-being ..." (RSA OP, 1996a). The promulgation of new environmental legislations in the mining- and other sectors, following the advent of democracy in the country, became necessary to give legal effect to the principles of sustainability as spelt out in the CRSA. As a result, the NEMA and the NWA were promulgated in 1998; and the MPRDA, dealing specifically with mining activities, in 2002 (See later Sections 4.2, 4.4 and 4.5, this article).

Section 195 (1) of the CRSA, sets out ethical values and principles, which must be held by all public servants and organs of state in carrying out their duties. Mining activities are one of the main listed activities that should be regulated to give effect to the environmental rights provided in the CRSA (Snyman and Brent, 2006). Further, Section 24 (b) of the CRSA provides measures for ensuring a safe environment in mining and disposal of resulting waste; and reiterates the moral obligation of mine management to prioritise the health of communities 
and environmental integrity during all phases of mine development, including closure, as is also imbued in NEMA (See Section 4.4, this article).

However, in spite of the proclamation in Section 195 (1) of the CRSA, when considering the effect of (improper) tailings handling, experience and conditions on the ground support the view that, in many instances, the constitutional rights of communities affected by mine pollution are often infringed (See e.g. Appendices I - III, this article).

\subsection{The Mineral and Petroleum Resources Development Act No. 28 of 2002}

The MRPDA (of 2002) (date of commencement, 1 May, 2004) states: "To make provision for equitable access to and sustainable development of the nation's mineral and petroleum resources; and to provide for matters connected therewith", requires a mine to have an environmental management programme report, which becomes legally binding (RSA OP, 2002). The report should contain the results of studies undertaken by the mining company to determine the quantum required for the rehabilitation or management of impacts, and to make sufficient financial provision for these. But it is argued that this is only applicable to the mine site.

The majority of the mine dumps which still dominate the South African mining landscape today are dumps created prior to the promulgation of the MPRDA. Although the old MPRDA does aim to provide for the protection of the environment at mine closure, Sutton and Weiersbye (2007) noted that it contains some flaws and gaps which needed to be addressed.

For example, from a mining regulatory point of view, the government agencies did not appear to have any control over those mine dumps (Sutton and Weiersbye, 2007; Feris, 2013). What that also meant was that the common law position relating to the ownership of mine dumps, despite the other fundamental changes to the mining legislation, still prevailed.

The Department of Mineral Resources (DMR) has attempted to correct this situation, and to ensure that Government, from a regulatory perspective, secures control over the historic mine dumps. This was done, firstly, by promulgation of the Mineral and Petroleum Resources Amendment Act 49 of 2008 (amendment to the earlier MRPDA), of which certain sections came into effect on 7 June 2013; and now, by means of the Mineral and Petroleum Resources Development Amendment Bill of 2013 (Roodt et al., 2012; Feris, 2013). Articles in the Amendment Act are now signed into law, but unfortunately, these are still unclear and certain clauses seem unworkable.

\subsection{The Code of Practice for Mine Residue Deposits}

Published back in 1998 by the South African Bureau of Standards (SABS, 1998), the principal management 'Guidance Document' for management of tailings facilities in South Africa is the CPMRD (SANS, 1998). This standard is referred to as SABS 0286:1998 [later re-named SANS (South African National Standards) 10286]. Articles in this Document engender the implementation of a code of practice that is mandatory for each tailings facility (Anglo, 2005). It contains the fundamental objectives, principles and minimum requirements for best practice, all aimed at ensuring that no unavoidable risks, problems and/or legacies are left to future generations (Kilani, 1998).

The standard was developed as a consequence of a major tailings impoundment failure in Virginia in the Free State in February 1994 (See Appendix I, this article), to address safety concerns relating to the structural failure, and how to prevent this from recurring. There are 
some inherent gaps in the Standards, such as provision of sufficient latitude for integrating the requirements of the EIA legislation, although these are potentially addressed by the provisions of other legislations such as the NEMA and NWA. The regulatory framework for mining residue stockpiles and deposits which has been under review (RSA DEA, 2010), has been replaced (in 2015) by a new set of requirements for mine dumps and stockpiles.

\subsubsection{The new stringent requirements for mine dumps and stockpiles}

Proclamation of new "Mining Residue Regulations" (MRR) was made by the Department of Environmental Affairs (DEA) on 24 July, 2015 to control the establishment and reclamation of mine dumps and stockpiles of similar waste from, or incidental to, mining operations (RSA GPW, 2015). These activities must now comply with the new regulations.

The MRR supersede regulation 73 of the MPRDA which previously regulated mining waste. Most of the provisions in the new MRR, however, echo those in regulation 73 of the MPRDA, albeit with some significant changes (Cullinan, 2015). For example, a waste management licence under NEMWA is now required for the creation of a residue stockpile, and an EIA process must be undertaken in accordance with NEMWA. Whereas under the old MPRD regulations, any registered engineer could design stockpiles where stockpiles had to be designed by a "competent person", the MRR now require that this be done by a civil or mining engineer, registered under the Engineering Profession of South Africa Act 114 of 1990. Stockpiles must also now comply with landfill requirements, the 'National Norms and Standards for the Assessment of Waste for Landfill Disposal, 2013', and the 'National Norms and Standards for Disposal of Waste to Landfill, 2013'.

Cullinan (2015) considers that the new MRR make the requirements for establishing and managing stockpiles and residue deposits more stringent and more expensive, but that they would lead to an enhancement in preventive measures.

Later reviews of regulations regarding the planning and management of residue stockpiles and residue deposits (e.g., Lake 2017) have advocated amendment legislations that would, inter alia ,allow for the pollution control barrier system required for residue stockpiles and residue deposits to be determined on a case by case basis, based on a risk analysis conducted by a competent person"; and the use of a "pollution control barrier system compliant with the commensurate norms and standards for disposal of waste to landfill determined as a result of the risk analysis ...".

\subsection{National Environmental Management Act No. 107 of 1998}

The NEMA reads: "To provide for co-operative, environmental governance by establishing principles for decision-making on matters affecting the environment, institutions that will promote cooperative governance and procedures for co-ordinating environmental functions exercised by organs of state; to provide for certain aspects of the administration and enforcement of other environmental management laws; and to provide for matters connected therewith". [(Long title amended by Section 3 of Act No. 56/2002, and substituted by Section 13 of Act No. 46/2003) (RSA DEA, 2009)].

The NEMA as amended, provides a broad, flexible legislative framework for environmental management in South Africa. It provides for cooperative environmental governance, and defines principles for decision-making on matters affecting the environment. Feris and Kotzé (2014) also 
noted that it provided a medium for responding to changes in socio-economic and ecological parameters. The application of this legislation, it was hoped, would help in protecting environmental resources and regulate harmful impacts on the environment. Also embedded in the amended Act, are articles pointing to the need for caution to be taken to ensure that the application of policies or related regulatory measures intended at protecting the environment should uphold the human rights values such as equality and dignity (Feris, 2013). The upholding of equality and dignity values helps in ensuring the consistent application of policies and avoiding creating false perception of the marginalised communities which could result in sustaining the structural disadvantage in unequal societies.

\subsection{The National Water Act No. 36 of 1998}

The International Commission on Large Dams (ICOLD) is a non-governmental international organisation which provides a forum for the exchange of knowledge and experience in dam engineering. Based on the principles enshrined in ICOLD's flagship document on dam safety, the first dam safety legislation in South Africa was promulgated by the then Ministry of Water Affairs way back in 1986 (RSA MWA, 1986; DBSA, 2004).

By the start of the post-apartheid environmental campaign in the mid 1990s, water was already deemed a common property resource owned by the people of South Africa and managed by the Government (Goldblatt et al. 2002). The National Water Policy White Paper and the NWA are based on the principles of equity, sustainability and efficiency (RSA OP, 1999). The NWA was amended in 1999 by the National Water Amendment Act No. 45 of 1999 (See Government Gazette No. 20706 of 06 December, 1999).

The implementation of the amended NWA in 1999, as well as floods in 2000, and droughts at that same time, forced the introduction of water tariffs, and brought attention to mine water issues (Cessford, 2004). Questions then arose on how the additional legislation in the form of the MPRDA will affect already existing uncertainties arising from the implementation of the NWA (Cessford, 2004).

In 2007, the Department of Water Resources and Forestry (DWAF) published the 'Best Practice Guidelines for Water Resource Protection in the South African Mining Industry', Document BPG A4: Pollution Control Dams (PCDs) (RSA DWAF, 2007). The BPG A4 Document gives the purpose and general principles of PCDs. In order to classify the geochemistry of the tailings a subsidiary to this Act came into consideration, viz., the Minimum Requirements Guidelines of the Department of Water Affairs, which is referenced in the MPRDA (Caldwell, 2010), including environmental legislations that cover other waste products.

According to Mukheibir and Sparks (2003), the country's new water laws have instituted a macroeconomic and environmental reform process in the sector, in which water rights have been separated from land rights and a 'water right', limited to a 'use-right'.

From the perspective of tailings handling, the water laws appear to lack proactivity with respect to developing the relevant protocols, monitoring programmes and operating procedures (Cessford, 2004). Even if there are no formal DWAF guidelines, advice on how this process can be set in motion should be provided directly by DWAF or by private consultants. This proactive approach, Cessford (2004) goes on to note, would ensure that formalising existing water uses and applying for new licences would be a relatively painless exercise. It would also provide consolidation with commitment to DWAF (and other stakeholders) that water be used optimally. 


\subsection{The Minerals Act No. 50 of 1991}

The Minerals Act No. 50 of 1991 was put in place: " To regulate the prospecting for, and the optimal exploitation, processing and utilisation of, minerals; to regulate the orderly utilisation and the rehabilitation of the surface of land during and after prospecting and mining operations; and to provide for matters connected therewith" (RSA OP, 1991). The Act provides statutory requirements enforcing environmental protection, the management of the environmental impacts and the rehabilitation of the affected environment of prospecting and mining in South Africa.

According to Swart (2003), the most important requirement concerning the environment and the rehabilitation thereof, is that an environmental management plan (EMP) based on an EIA, must be submitted and officially approved. The Minerals Act (1991) requires in section 38, that the rehabilitation of the surface of land concerned in any prospecting or mining shall be carried out by the holder of the prospecting permit or mining authorisation concerned, in accordance with the EMP approved in terms of section 39 of the Act; and as an integral part of the prospecting or mining operations concerned throughout the life of the operation, until closure.

An amended version of the EMP was published by the Department of Minerals and Energy (DME) in February, 2001, under Section 15 (2) (b) of the NEMA (of 1998) (RSA DME, 2001). The inclusion of monitoring and performance assessment into the mining environmental management process is meant to complete the last link of an integrated, cradle-to-grave environmental management process adopted by the DME (Swart, 2003). The monitoring and EMP performance assessment process also assists Government as well as the mining industry in determining compliance with the requirements of the EMP, the appropriateness of the EMP, and to guide mines towards effective and acceptable closure.

\subsection{National Environmental Management: Waste Act No. 59 of 2008}

Waste management in South Africa is governed by the NEMWA (of 2008), which came into effect on 1 July 2009. It states: "To reform the law regulating waste management in order to protect health and the environment by providing reasonable measures for the prevention of pollution and ecological degradation and for securing ecologically sustainable development; to provide for institutional arrangements and planning matters; to provide for national norms and standards for regulating the management of waste by all spheres of government; to provide for specific waste management measures; to provide for the licensing and control of waste management activities; to provide for the remediation of contaminated land; to provide for the national waste information system; to provide for compliance and enforcement; and to provide for matters connected therewith".

Following the enactment of the NEMWA (of 2008), the Ministry of Environmental Affairs (MEA) established the National Waste Management Strategy (NWMS) in terms of Section 6 (1) of the NEMWA for achieving the objects of the Act. The NWMS was approved for implementation by the Cabinet in November 2011. The NEMWA supports the waste management hierarchy in its approach to waste management, by promoting cleaner production, waste minimisation, reuse, recycling and waste treatment, with disposal seen as a last resort in the management of waste.

General, hazardous and industrial wastes from the mining industry also fall within the scope of the NEMWA, and therefore are addressed by the NWMS. However, Section 4 (1) (b) of the NEMWA specifically excludes residue deposits and stockpiles from its ambit, as much as these are regulated in terms of the MPRDA. In terms of the amendment to the MPRDA, responsibility for the performance of environmental authorisations was reverted to the DEA. The promulgation of 
the National Environmental Management Laws Amendment Act No. 25 of 2014 (NEMLAA), amended the Waste Act to include residue stockpiles and deposits (Gore and Erasmus, 2015). The reasoning for setting aside NEMLAA was that it required residue stockpiles and deposits to be managed in the 'prescribed manner'.

\subsection{The National Environmental Management: Air Quality Act 39 of 2004}

The original Act regulating air quality, the Atmospheric Pollution Prevention Act No. 45 (APPA), was promulgated way back in 1965. It provided for the prevention of pollution of the atmosphere, for the establishment of a National Air Pollution Advisory Committee, and for matters incidental thereto (RSA OP, 1965). The obligations contained in terms of the APPA with respect to the prevention and control of dust pollution are in addition to- and complimentary with, the obligations imposed by the Minerals Act No. 50 of 1991 (see Section 4.6, this article). The APPA is now superseded by the NEMAQA.

The NEMAQA was promulgated in 2004, “... for reforming the law regulating air quality, in order to protect the environment by providing reasonable measures for the prevention of pollution and ecological degradation, and for securing ecologically sustainable development, while promoting justifiable economic and social development" (RSA OP, 2005). Further, the Act provides for national norms and standards regulating air quality monitoring, management and control by all spheres of government for specific air quality measures; and for matters incidental thereto (RSA OP, 2005).

Principles from Chapter 1 of the NEMA (See Section 4.4, this article) that are relevant to air pollution are:

- pollution avoidance or minimisation - that pollution and degradation of the environment must be avoided, or, where they cannot be altogether avoided, are minimised and remedied;

- waste avoidance and consideration of life cycle assessment - that waste is avoided, or where it cannot be altogether avoided, it must be minimised and re-used or recycled where possible, or disposed of in a responsible manner (RSA DEA, 2009).

\subsection{The Mine Health and Safety Act29 of 1996}

The Republic of South Africa MHSA (of 1996) “... provides for protection of the health and safety of employees and other persons at mines" (RSA OP, 1996a).

The Act is administered by the Mine Health and Safety Inspectorate of the DME. The following sections apply to tailings handling and mine closure employees:

- Sections 2 and 5, where the employer must ensure and maintain a safe and healthy environment at the mine, during commissioning, operation, decommissioning and closure;

- Sections 6, 10 and 11 make provision for the employer to provide and supply adequate health and safety equipment, training and assess, and respond to any risk or hazard to which employees may be exposed;

- Sections 12 and 13 pertain to the medical surveillance system; 
- Sections 19, 22 and 23 pertain to employees' rights with regard to access to information, duties for health and safety and permission to leave a dangerous working place if circumstances arise (RSA OP, 1996b).

\subsection{The Radioactive Waste Management Policy and Strategy for the Republic of South Africa}

The vision of the South African Government regarding radioactive waste is that: "The management of radioactive waste shall be in accordance with national objectives and recognised international principles as set out in Government Policy" (RSA DME, 2005). The aspect of internationalisation imbued in this vision, adjures elements in the review of ethical and environmental considerations that must be taken into account in the long term management of radioactive wastes by the World Nuclear Association (WNA, 2006). Thankfully, the Association noted in its 2006 Document, that there has been a steady growth in public appreciation (globally) that nuclear sites operate safely with due care for the protection of people and the environment. This (positive) appraisal is a natural consequence of comprehensive health, safety and environmental programmes that conform with general regulatory frameworks worldwide, and not specifically to any country or region.

As recently as the mid-2000s, radioactive waste in South Africa was managed without a common framework (RSA DME, 2005). "The radioactive Waste Management Policy and Strategy for the Republic of South Africa" was put in place in 2005 to correct this. The purpose of the Document was: "To ensure the establishment of a comprehensive radioactive waste governance framework by formulating, additional to nuclear and other applicable legislations, a policy and implementation strategy in consultation with all stakeholders" (RSA DME, 2005).

There exist a number of earlier legislations regulating radioactive waste disposal in South Africa, which together with the later Acts, make identification of the Act that is applicable in a particular situation, and its mode of articulation, confusing. A few of the earlier (waste) Acts that have sections relevant to tailings disposal are now briefly reviewed.

The NEMWA excludes radioactive waste and mining "residue deposits and residue stockpiles" from its ambit. It states that these are regulated in terms of the National Nuclear Regulator Act No. 47 of 1999 (NNRA), the Minerals Act and the MPRDA, among others. In reality, they are not, for as Liefferink (2011) noted, the NNRA and MPRDA applied only to waste actually on a mine property, and not that outside it. Any spillage, or migration, of radioactive and toxic waste is therefore not regulated under the MPRDA. Nor was it regulated in terms of the NNRA, which only regulated this waste when it was on mine property.

The more recently proclamated National Radioactive Waste Disposal Institute Act No. 53 of 2008 (NRWDIA) states: "To provide for the establishment of a National Radioactive Waste Disposal Institute in order to manage radioactive waste disposal on a national basis; to provide for its functions and for the manner in which it is to be managed; to regulate its staff matters; and to provide for matters connected therewith". Among the Institute's specific functions are (ii) the design and implementation of disposal solutions for all classes of radioactive waste, and (ii) the development of radioactive waste acceptance and disposal criteria in compliance with applicable regulatory health and safety environmental requirements, and any other technical and operational requirements.

\section{Ethical values and CSR}

Before the beginning of the 2000s the absence of a widely agreed framework for defining CSR in mining circles was already apparent (e.g., Kolk et al. (1999). The concept did not specify 
minimum outcome-based standards of health and social enabling milieu for companies whose activities are harmful to the health and social well-being of communities. Mining companies were able to externalise many of their costs to pass themselves off as socially responsible. What this did in practice, according to Fooks et al. (2013), was “ ... to involve mining companies in the use of CSR to broker access to public officials, influence the policy alternatives under consideration by elected representatives, break up opposing political constituencies, rebuild companies' reputations as providers of reliable information and as a platform for strategic regulation". Capel (2012) cites reports of blackmail, lack of cooperation by mining houses, and involvement of current and former government officials as shareholders, board members or managers in mining companies, all of which actions present a whole set of complications and tensions. Before the new environmental dispensation, there was no general agreement on how to create indicators to assess the social responsibility of mining enterprises (cf. Clarkson, 1995). Moreover, studies that systematically compare codes of mining firms from different countries were generally lacking. In addition, examinations of contents of codes by different actors governments, social interest groups and firms themselves - were rather inadequate (Kolk et al., 1999). Finally, the policy challenges created by the interaction of often rival codes were hardly addressed (Kolk et al., 1999).

\subsection{Present status in articulation of CSR in South African mining}

In South Africa today, all stakeholders in the mining industry recognise that in order to ensure that social environment needs are addressed during the life of the mines, and during post-closure, mines have to contribute towards social and economic development in areas where they operate, and in areas where they source their labour (Mabuza et al., 2010; Campbell, 2012; Fooks et al.; 2013; Diale, 2014). However, according to Flores-Araoz (2011), the South African Companies (SAC) Act 61 of 1973 does not oblige companies to engage in CSR projects, although the country's Policy Document and the King Reports (Section 5.1.1, this article) explicitly address the need and relevance for corporations to acknowledge all stakeholders and to adopt a "triplebottom line" approach. It should be noted, however, that certain mining companies had long seen this need (even before the SAC Act 61 of 1973 and the more recent King Reports), and are willing to take responsibility for their company's effects on environmental and social wellbeing. Some have even applied efforts that go beyond what may be required by regulators or environmental protection groups. Sadly though, there are still many mining companies that use CSR to produce policy outcomes that work against public welfare; and, according to Fooks et al. (2013), our understanding of the limitations of CSR as a means of aligning business activity with the broader public interest, remains relatively low.

Recently, Diale (2014) provided an assessment of the progress made by South African mining companies in pursuit of responsible business practices. He refers to the notion of CSR as a discourse, and explains how it is conceived within the mining industry. Diale (2014) further reflects on the *Mining Charter as a framework for responsible business within the mining industry and analyses the progress achieved so far. Developments that have led to Diale's (2014) observations are summarised in the earlier works of Mariri and Chipunza (2011), who had compared corporate priorities of corporate governance, CSR and sustainability within the South African mining industry, and showed that social performance is the most highly reported sustainability dimension.

Finally, according to Fooks et al. (2013), “ ... the extent to which CSR practices can bring corporate activity more closely into line with the broader public interest is predicated on their capacity to make corporations more accountable to stakeholders whose interests are not purely confined to optimising returns on capital invested". 
*The 'Mining Charter' means the broad-based socio-economic empowerment Charter for the South African Mining and Minerals industry (RSA DMR, 2010).

\subsubsection{The King Reports - the "Codex" of South African CSR}

South Africa's corporate governance guidelines and standards are contained and institutionalised in the well-known King reports (Engelbrecht, 2009), the first of which was issued in 1994 by the King Committee on Corporate Governance. Today, these reports are regarded as state-of-the-art guidelines regarding good corporate governance, and their adoption is highly popular, with many legislators recommending it as apposite for modulating the country's business sphere.

The first King Report or King I was published in 1994. It aimed at promoting corporate governance and adherence to adequate standards for board of directors of listed companies, financial institutions and some public enterprises (Cliffe Dekker Attorneys, 2002).

Published in 2002, the King II Report clearly established and explained the seven good corporate governance elements that any corporation adopting the report should pay attention to: discipline, transparency, fairness, social responsibility, independence, accountability and responsibility (Engelbrecht, 2009).

The revised code of-, and report on, 'Governance Principles for South Africa' (King III) were released on 1 September 2009, and came into effect on 1 March 2010. The report focuses on sustainability and risk issues, while continuing to highlight the importance for companies to respond to all stakeholders (SAICA, 2013). The topics covered in the report are: ethical leadership and corporate citizenship, boards and directors, audit committees, the governance of risk, the governance of information technology, compliance with laws, rules, codes and standards, internal audit, governing stakeholder relationships and integrated reporting and disclosure.

\subsubsection{The concept of neutralisation}

Writing on different company approaches to CSR practices, Fooks et al. (2013) used the tobacco industry as an example to show how the concept of 'neutralisation' can help us understand why companies only superficially address the important ethical issues. Corporate decision-makers, when facing a combination of social censure and increased regulatory risk (manifestations of declining political authority), at first reject, and then contest the arguments of policy entrepreneurs and reform minded policymakers using techniques of neutralisation. Fooks et al. (2013) present a tripartite model of the neutralisation process (Fig. 4) - in the first of which, reliance by corporate decision-makers on techniques of neutralisation provides the basis for declining political authority to be seen as a problem arising from poorly designed and coordinated political strategies (rather than a growing awareness of the company's conduct and its social impacts). 


\begin{tabular}{|c|c|c|c|}
\hline & Stage One & Stage Two & Stage Three \\
\hline $\begin{array}{c}\text { Declining Political } \\
\text { Authority }\end{array}$ & $\begin{array}{l}\text { Techniques of Neutralisation } \\
\text { (Psychological framing) }\end{array}$ & $\begin{array}{c}\text { Techniques of Neutralisatio } \\
\text { Organisational Myths } \\
\text { (Organisational framing) }\end{array}$ & $\begin{array}{c}\text { Political CSR } \\
\text { (Ideological framing) }\end{array}$ \\
\hline 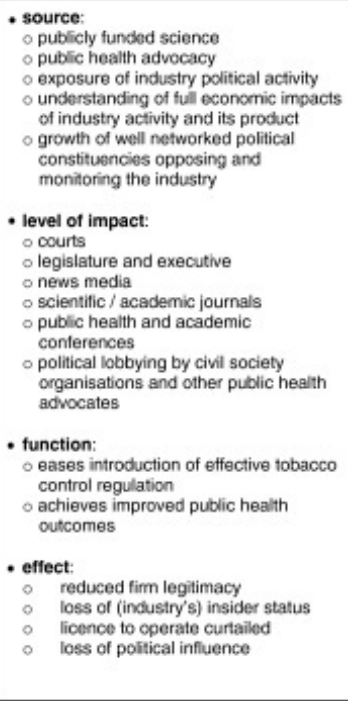 & $\begin{array}{l}\text { - source: conceived in response to } \\
\text { criticism of the company } \\
\text { - level of impact: work at the level } \\
\text { of individual psychology / } \\
\text { oognition } \\
\text { - function: } \\
\text { o prowide a series of excuses to } \\
\text { and justifications for firm } \\
\text { criticism } \\
\text { o allow managers to conceive of } \\
\text { themselves and their company } \\
\text { as socially responsible in the } \\
\text { absence of substantive attempts } \\
\text { to address the basis of criticism } \\
\text { - effect } \\
\text { oform the underlying justification } \\
\text { of socially suboptimal CSR } \\
\text { o legitimise organisational myths } \\
\text { (see Stage 2) that lead to the } \\
\text { establishment of socially } \\
\text { suboptimal CSR programmes }\end{array}$ & 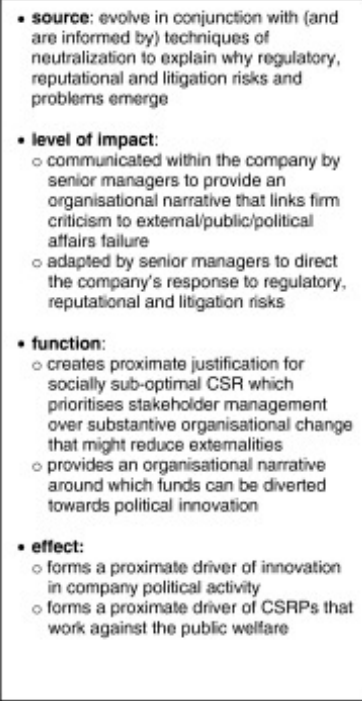 & 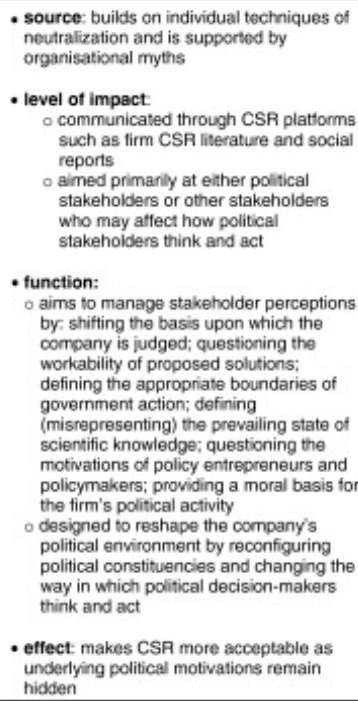 \\
\hline
\end{tabular}

Fig. 4. Techniques of neutralisation as they apply to corporate actors. Source: Adapted from Fooks et al., (2013).

During the second stage, according to the model of Fooks et al. (2013), corporate decision-makers start attributing the company's declining political authority to external social actors and proceed to design alternative - and potentially more effective - forms of political management (namely CSR) to annul their impact. In the third stage, corporate decision-makers embed techniques of neutralisation within the firm's CSR to legitimise CSR practices that work against public welfare (by reducing political support for regulatory change).

This explanation by Fooks et al. (2013) of the neutralisation concept could, perhaps, with minor modification be applied in understanding the way tailings disposal operatives perceive ethical issues. They see their resistance to regulatory change as consistent with the broader public interest, and try to draw a distinction between sensible and unreasonable regulation, and building a constructive case for the company's existing commercial freedoms.

\section{Compliance monitoring}

Kolk et al. (1999) have observed that the likelihood of compliance depends on the contents of the code addressed, but is also heavily influenced by the interaction of various stakeholders in its formulation and implementation. According to Capel (2012), “... there is a role for independent monitoring and evaluation and a role for community monitoring to hold mining corporations accountable".

Nowhere is the problem of compliance, implementation and enforcement of laws more problematic than in the realm of EIAs (Capel, 2012). In some cases, communities are not consulted as prescribed in legislation (See Section 7, this article), while in many other instances, only token public consultation processes are undertaken by mining companies to make it look as if they are complying with the law. Capel (2012) asserts that these mining companies really have no intention of listening to local people or implementing concrete steps to curb environmental damage and protect communities. Furthermore, most EIAs appear to be based on the incorrect assumptions by 
mining companies and their consultants, who believe they have ready-made solutions to potential problems.

Another flaw of EIAs according to Capel (2012), is that they are produced by the mining company or developer of the project, and this means there is no independent assessment. Meanwhile, effective implementation and monitoring is often restricted by the relevant ministry's lack of financial and human resources. It is perhaps in the area of compliance monitoring where community participation, which also takes into account gender sensitivity, in policy formulation, is most strongly desired.

\section{A place on the table: inclusivity in formulation of statutes}

Grunwald (2015) has noted that all members of the society must have the opportunity to participate in societally relevant decision-making processes, especially regarding those decisions that are of key importance for the future development and shaping of the society.

In South Africa, the communication with communities affected by inappropriate tailings management is weak. They are merely informed of management decisions, but their consent is seldom sought. It is worth noting what the Alternative Mining Indaba in 2014 had to say (direct quotation): "We continue to note with concern, that the *African Mining Indaba (being held at the International Convention Centre in Cape Town), has once again excluded the true owners of the land from their conference, and warn that severe hardship, social conflicts and unsustainability will result when our land and heritage is sold at the altar of foreign governments and transnational corporations.

We stand in solidarity with workers, women and men, young and old, who have lost their lives and livelihoods as a result of unscrupulous mining companies, and demand the protection of the rights of communities and particularly the defenders of rights, who continuously suffer under oppressive regimes ..." [http://www.news24.com/Archives/City-Press/Alternative-Mining-Indaba-calls-forinclusion-of-communities-20150429 (accessed 11.03.16)].

*'The African Mining Indaba' is an annual professional conference dedicated to the capitalisation and development of mining interests in Africa.

Beierle (1999), and Beierle and Konisky (2001) examine the need to increase public participation in environmental decision-making processes, and propose the use of a framework that evaluates the outcomes of participatory processes using a set of six "social" goals which he matches to the participatory mechanisms by which they might be achieved. These authors conclude by outlining areas for further research that are suggested by the framework.

Fostering public participation would enable the affected communities recognise the vital importance of the mining industry to modern society and to the local economy, and continue to expect responsible stewardship of the environment by this essential industry. Goodland (2012) and CER (2013) take the need for inclusivity a step further by advocating that communities be afforded a chance to actually participate in the data collection and their interpretation as well, and not merely make an appearance in public meetings.

\subsection{The place of women on the table}

Women, in particular, must be encouraged to participate in decision making processes as well as on all negotiations concerning the development of tailings facilities and other mining related activities. This should be as a natural consequence of their traditional role in acquiring most of the elements 
needed for ensuring family sustenance. They constitute the higher proportion of primary care givers for those affected by improper tailings handling and other mining impacts (See Section 3, this article). McGuire (2003) corroborates these assertions and emphasises that women need to be better informed about these impacts, and their interests and welfare made part of the agenda in mining indabas.

\section{Mining ethics and sustainability in tailings management}

By the advent of the new environmental dispensation in South Africa in the mid-1990s, the mining industry had taken note of the continued and growing momentum behind sustainable development (McDonald, 2002). Busacca (2013) examines how concerns about the social responsibility and sustainability of South Africa's mining industries have become increasingly important and mainstream in recent years. A look at the historical evolution of the legislative processes regulating management of tailings dams in South Africa reveals that standards and guidelines are becoming increasingly prescriptive as regards procedural and technical requirements. There is some convergence around the norm for the design of a tailings disposal facility, and sustainability is now a closure requirement (Van Eeden et al., 2009). However, institutional factors as well as noneffectiveness and inefficiency of guideline dissemination and implementation strategies do not make for sustainability.

Corporate citizenship and sustainability require business decision makers to adopt a holistic approach to economic, social, and environmental issues in their core business strategy, and according to Porter and Kramer (2006), only a holistic approach will allow for the effective management of business opportunities and risks. The implementation of sustainable development implies also a governance system that ensures the participation of all in the decision making process (Bisaillon et al., 2005; See Section 7, this article). According to Robinson (2010), there could be no single complete answer, but rather an elaboration of the complexity of the topic. On the issue of mine closure alone, for instance, sustainability has many profound ramifications, including environmental acceptability, safety, long-term stability, and hydrological considerations (See Sangonet, 2013; Irina and Stückelberger, 2014). Above all, the future of the workers and the community is paramount since they are threatened with no livelihood after cessation of the mining activity.

\section{Addressing the issues}

It is clear from a retrospective look at the state of tailings dams around the country, and the evolution of practices and expectations, that improvements have been made in some areas of concern. Reporting on environmental and social issues has improved. But it is also important to distinguish between the improvements in standards and norms, and real improvements in performance. The same can be said for improvements in reporting and transparency versus improvements in minimising negative impacts (e.g., tailings dam failures or AMD formation) and maximising benefits (e.g. tax payments).

There remains much room for improvement in crafting and revising legal codes, and for seeking better ways of articulating existing regulatory instruments for tailings management for the protection of the environmental health of exposed populations. Current project management models for the development and management of these facilities do not as yet provide a holistic approach to integrate the requirements of the various existing regulatory statutes during the various project life cycle phases (from EIA process and pre-mining, right up to mine post-closure). Such failings have a dreadful effect on sustainable development of mining communities. 
We submit in summary form, 5 imperatives that hopefully would contribute in future review and articulation modes of tailings disposal statutes in South Africa:

\subsection{Imperatives on responsible tailings management}

\subsubsection{Imperative 1: Giving the devil his due, but coming out strongly on defaulters}

There exist a number of mining industry operators that deserve praise for their efforts towards the proper management of tailings. Cite, and acknowledge them. Concentrate on factual accounts of incidents to develop and maintain credibility. In concordance with Davies' call (2001): "Avoid supporting non-government organisations that endorse actions against corporations committed to a high degree of environmental stewardship, and who operate their mines and tailings facilities accordingly".

However, it is important to distinguish between the improvements in standards and norms, and real improvements in performance (e.g., Hart and Coumans, 2014). The same can be said for improvements in reporting and transparency versus improvements in minimising negative impacts from improper tailings disposal and other mine waste removal practices.

In this connection, we have to stress the evolution of disturbing trends in the legal framework, with insufficient government involvement in environmental assessment. Although these trends are hard to quantify, we do not see any real indication that the number of on-the ground social conflicts are decreasing, suggesting that the performance of the sector still has a long-way to go. Legal compliance to ensure protection of human health and environment and prevention of pollution is essential. Many environmental activists would like to see application of the 'polluter pays principle' whereby industries and polluters are forced to take full responsibility for the pollution they cause. It is possible for civil society and the relevant organs of state to co-operate in holding mining companies responsible and liable for alleged environmental contraventions and failure in their duty of care.

\subsubsection{Imperative 2: Create a strong stakeholder management base}

The success of responsible tailings management depends on the collective actions by all key stakeholders (Section 2.1, this article). The mining corporate has however, additional responsibilities, in ensuring that it conducts its business in a way that ensures the promotion of high moral and environmental etiquette among workers.

In the South African context, responsible mining would promote relationships between various stakeholders involved or affected by tailings management as well as other mining operations.

Snyman and Brent (2006) propose that to avoid the manifestation of undue risks and ensure the optimisation of resource exploitation, owners of mines and practitioners of tailings disposal must conduct disposal practices in accordance with fundamental safety and environmental objectives and principles as laid out in a set of performance criteria. Martin et al. (2002) submit that mine owners should move from an end-of-pipe approach to tailings management to a more integrative approach, recognising that effective tailings management must begin in the extraction process, not at the end of the pipe. It is important to recognise the critical importance of making the right decisions at the outset of a project, and accounting for long-term closure costs and liabilities in financial evaluations of existing and potential projects.

Prior to business operations beginning, Capel (2012) believes that a local barometer should be used, drawing expertise from civil society to ascertain potential human rights impacts as they 
pertain to the social, economic, environmental and health consequences of operations. Government and the community should work together to the extent that a project that fails to garner consensus from all stakeholders should not be allowed to proceed.

\subsubsection{Imperative 3: Strengthen regulatory measures}

The South African regulatory framework (Fig. 5) provides for the operation and monitoring of the activities pertaining to environment and human health. These are source documents that need to be understood and consulted to address activities that have a potential to harm human health and degrade the environment.

Davies (2001) recommends that regulators establish and maintain a database on all tailings dams, operating and otherwise, within their jurisdiction. Honest assessments of the performance records of owners and designers should be made, and the details shared with other regulators as appropriate. They should facilitate development where the owner presents an independently reviewed design that is consistent with standard design criteria. 


\section{Advocacy \& Networking}

Civil I Society Environmental Rights

\section{Monitoring:}

National Health Act, 61 of 2003;

National Water Quality Act, 36 of 1998;

National Environmental Management

(NEMA): Air Quality Act, 39 of 2004;

National Environmental Management

(NEMA): Waste Act, 59 of 2008

\section{Operational:}

Mineral \& Petroleum Resources

Development Act., 28 of 2002;

Mine Health \& Safety Act, 29 of 1996

\section{Overaching Environmental Rights Law:}

National Environmental

Management Act (NEMA), 107 of 1998

\section{Supreme Law:}

The Constitution of the Republic of South Africa, 108 of 1996

Fig. 5. An illustration of an ideal South African regulatory framework relevant to responsible tailings management.

\subsubsection{Imperative 4: Promote an ethical mining culture}

The creation of an ethical culture within the mining companies demands the companies' commitment to understand and uphold the current applicable statutory requirements. Ethical culture in the mining companies guarantees that justice is done for all affected parties and in all circumstances. Figure 6 provides a summary of key ethical elements essential for creating an ethical mining culture. 


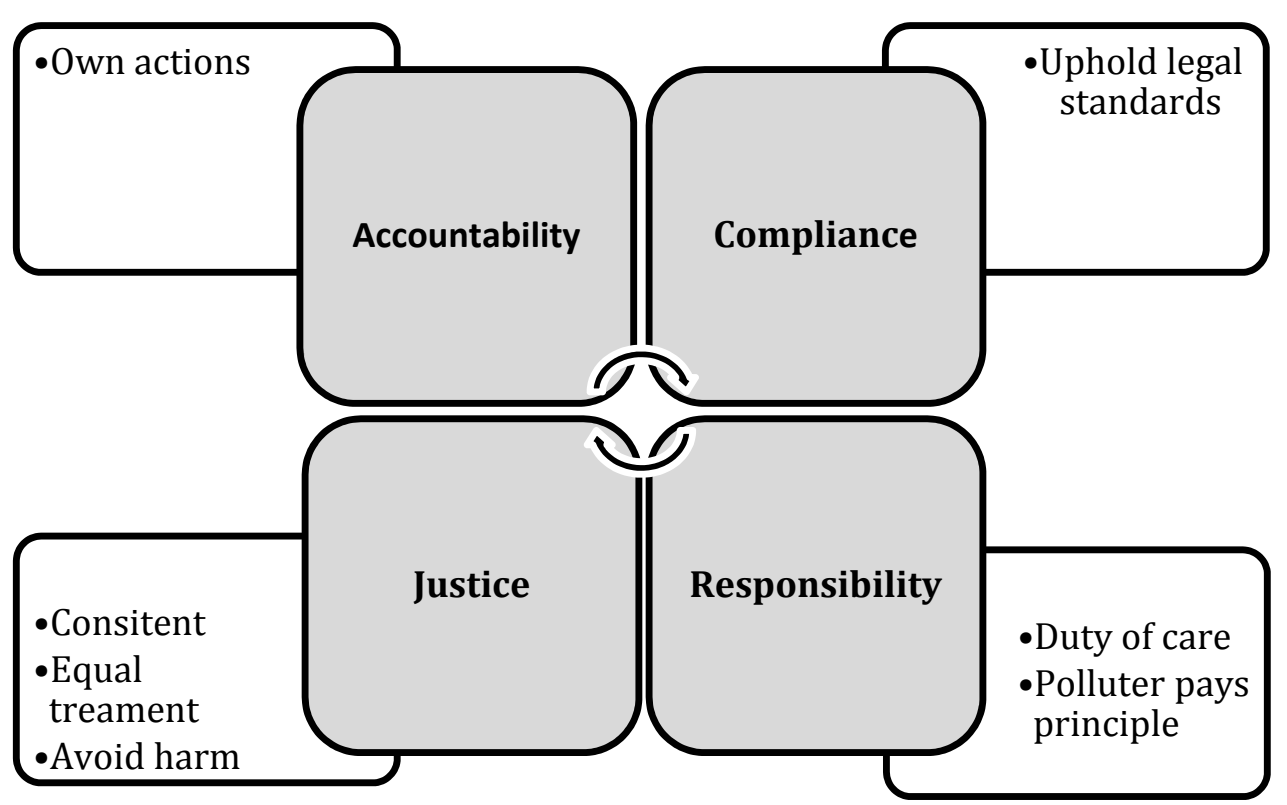

Fig. 6. Suggested key elements for an ethical tailings disposal practice in South Africa

An ethical mining culture would promote the development of strategies that deal with unintended consequences. The ethical principles of beneficence and non-maleficence refer, and their application would restore the dignity of the people.

The benefits of responsible tailings disposal can only be derived when mine operators faithfully apply principles designed to avoid hazards and the creation of a conflict-free relationship between the local communities, the mining industry and the government

According to Capel (2012), "All activities of a company should have a positive impact on all stakeholders especially those most oppressed and exploited. There is the need to capacitate communities to engage with mining houses on a level playing field in order to enhance sustainable development".

\subsubsection{Imperative 5: Tailings should be usefully applied}

Although the operation of South Africa's tailings dams goes as far back as the early 1960's, there is still uncertainty with regards to the sustainability of the vegetation cover established using different rehabilitation methods; and there remains a general dearth of research and knowledge on the different rehabilitation technologies. In the field of 'phytoremediation', however, South African researchers are among the leaders. This green technology is being developed by a number of mining companies in the country, such as AngloGold Ashanti and Rustenberg Base Metals Refiners. The technology involves growing 'tolerant plants' in a contaminated matrix to remove environmental toxicants by immobilisation (phytostabilisation) or extraction (phytoextraction) (Sharma and Pandey, 2014; Arthur et al., 2015). One of the main advantages of phytoremediation is that of its relatively low cost compared to other remedial methods such as excavation.

Berkheya coddii Roessler (Asteraceae), an endemic herbaceous and perennial nickelaccumulating plant grows on Ni enriched ultramafic soils in South Africa. This plant is perceived as a promising species for phytoremediation and phytomining due to its large biomass production and high nickel content. B. coddii, is presently cultivated commercially by Rustenberg Base Metals Refiners, and has been tested for phytoremediation of cadmium, nickel, zinc and lead from industrial tailings and wastewater effluents at disposal sites (Mesjasz-przybyłowicz et al 
2004). AngloGold Ashanti is also looking at the use of indigenous vegetation to prevent pollution in the form of dust and AMD from tailings dams.

Mineral tailings produced by a number of South Africa's mines are composed of silicates, oxides and sulphides. A number of researchers have applied engineering techniques to study the potential of these materials to be recycled into innovative schemes designed to reduce their footprint and to evaluate their suitability for mineral carbonation, e.g., Amponsah-Dacosta and Reid (2014), and for brick-making, e.g., Malatse and Ndlovu (2015).

Mentjes (2014) has reviewed the benefits of dry tailings disposal as one of the most waterefficient waste management systems, and has advocated the consideration of their use for both existing and new mining projects. To achieve real cost benefits, it is necessary to integrate the design of process plant with that of tailings disposal while giving consideration to all design aspects, from site selection to closure of tailings impoundments. Mentjes (2014) also discusses the geotechnical properties of tailings and shows how water savings can be made and groundwater pollution reduced by changing the tailings from wet slurry into a dry product.

Some mining companies are now exploring the advantages of re-processing of legacy tailings resources to extract minerals such as uranium and gold. The technique is becoming attractive, because of the potential to maintain margins and unlock profit. Tailings reprocessing is also viewed favourably from an environmental standpoint, in that it allows for additional production without increasing a mine's footprint. It provides a platform for advancing research in reprocessing technology and phytoremediation, and does not require additional land permits.

The problems associated with mine tailings disposal, both operational and legal, are not just specific to South Africa. Novel techniques are currently under development elsewhere on the use of such materials on an industrial and global scale to sequester ambient $\mathrm{CO}_{2}$, while research on the topic is constantly expanding. Ultramafic mining residues produced during mining operations around the world, such as in stockpiles, may offer a long-term solid storage buffer of atmospheric $\mathrm{CO}_{2}$ (IPCC, 2008).

Assima et al. (2013) have made a comparative study of five Québec (Canada) ultramafic mining residues for use in direct ambient carbon dioxide mineral sequestration. A number of studies outside South Africa have also estimated other ultramafic mining residues that contain high enough amounts of magnesium (12 - 19 wt. \%) able to chemically bind to ambient $\mathrm{CO}_{2}$ via above-ground natural weathering mechanisms (e.g., Beaudoin et al., 2008).

Experiences and lessons learned from applications in other top mining countries (e.g., Australia, Canada) can be applied to South Africa today.

\section{Conclusions}

Safe and environmentally responsible disposal of mine tailings is a major concern in South Africa's mining industry. The extent of the legacy of negative environmental and human health impacts is hard to quantify precisely. But we know that the amount of tailings produced by low grade, high tonnage operations is huge; and it is progressively increasing its environmental footprint.

A review of the evolution of South Africa's regulatory codes and the ethical position, as well as the behaviour of major mining companies in the area of tailings management, shows that, despite the new constitutional reforms, environmental management of tailings is still not strictly 
regulated, lax, nor enforced, or is overruled for several reasons. An overview of their contents and soundness, as well as their impact, is given in this study - the many loop-holes, the vestiges of exploitative colonial mining laws that remain entrenched in the older legislations (before mid1990s); and areas where the newer legislations (after the mid-1990s) fall short of adequately addressing constitutional and environmental requirements. Other aspects of the minerals legislation are shown to be in need of clarification or further development.

The nature of ethical concerns and the magnitude of the environmental and health hazards posed to South Africans by improper tailings management points to the conclusion that mining companies should uphold their own responsibility for the protection of the environment and our planet for the sake of present and future generations. Mining corporations are seldom held accountable for many of the social, environmental and health burdens that improper tailings handling impose on society. The line between what is their responsibility and what is not, is still very blurred. There are still low levels of accountability, transparency and commitment in all aspects related to CSR and sustainable development in tailings handling.

There is thus a clear need for a systematic approach to address these mammoth challenges. The core ethical principles of tailings management apply across the world, and deep knowledge and experience of the potential impacts are essential to readily transfer and monitor these principles adroitly, so that applications ensure ethical sanctity. In addition to these guidelines and regulations, procedures for safety management and documentation successfully applied in other high-risk industries should be adopted for operation of tailings impoundments. It is possible to design, operate, and close these facilities safely, and in ways that protect the environment.

Finally, the usefully application of tailings, such as in mineral recovery from historic dams, and the rock cladding of tailings dams for controlling wind and water (rainfall), as well as stabilise the slope of a mine dump, should be given more research attention. The use of revegetation in conjunction with rock cladding on mine dumps should be further explored.

\section{Acknowledgements}

The support provided by Mr. M. Kgware is highly appreciated. The Director of Research of Mangosuthu University of Technology, Dr. Anette Mienie, is thanked for financial and technical support of research related matters. Dr. K. Behrens of Steve Biko Bioethics Centre, University of the Witwatersrand and Dr. T. Balfour-Kaipa of the Chamber of Mines, South Africa, also gave invaluable inputs.

We are grateful to all the researchers and their institutions for making available the rich body of literature, images and photographs from which sections of this work, including the case studies, were based. All copyright is retained by them.

\section{APPENDICES:}

\section{CASE STUDY 1. Causes and consequences of the Merriespruit tailings dam failure.}

Excerpted from: Van Niekerk and Viljoen, 2005 (Direct quotation)

"On the night of 22 February 1994, the $31 \mathrm{~m}$ high northern wall of the number four tailings dam of the Harmony Gold mine collapsed. The tailings dam is situated $320 \mathrm{~m}$ up-slope of Merriespruit, a suburb of Virginia in the Free State Goldfields of South Africa. More than 2.5 
million tonnes of liquefied tailings ripped through the sleeping mining village. Eighty houses were largely swept away and 200 others were severely damaged. Seventeen people were killed.

The failure of this tailings dam shocked everybody who followed the unfolding drama of loss of life and destruction of property in the press. At the inquest following the disaster, the judge called this tailings dam a time bomb that was waiting to explode. For the first time in South African history, processed satellite images were allowed as scientific evidence in court. Together with eyewitness reports, all the evidence pointed overwhelmingly to the cause of the failure as being overtopping. The owner, the operator and six of their employees were subsequently found guilty of negligence (contravening Section 37 of the Minerals Act), and heavy fines were imposed.

The Merriespruit disaster provided the State and the mining industry with the impetus to ensure the safe disposal of tailings. It also made the mining industry and all those involved with the design and operation of tailings dams take stock of their management and tailing disposal methods".

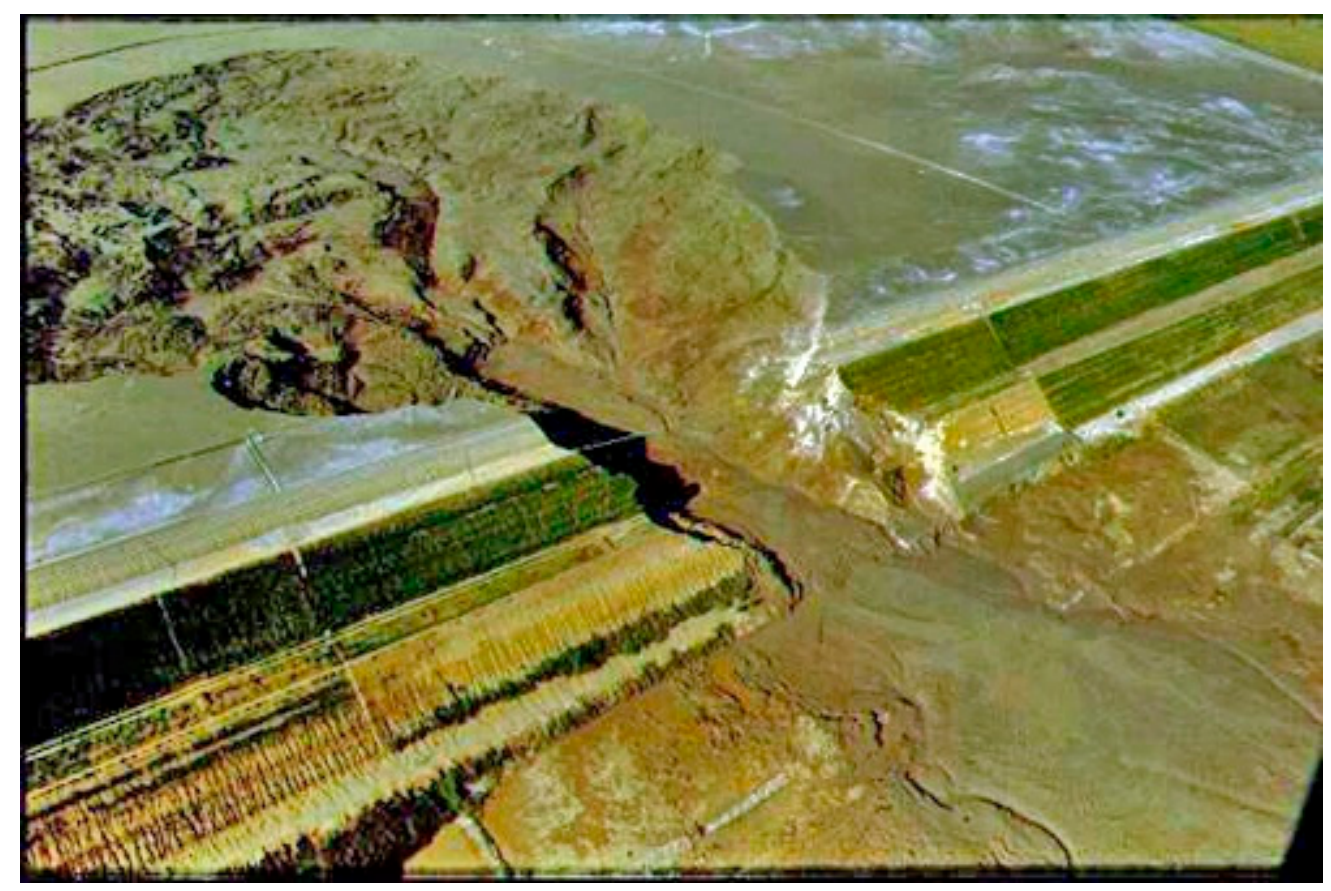

Appendix Fig. A1. Aerial view of the Merriespruit tailings dam disaster. Approximate volume of the dam $=2.5$ million cubic metres. Source: Tailings.info. Available at: http://www.tailings.info/casestudies/merriespruit.htm (accessed 26.03.16).

\section{CASE STUDY 2: Interviews with Tudor Shaft Community Members - 17 January 2013}

Excerpted from: Caincross et al., 2013 (Direct quotation).

"About 2000 residents continue to live in shacks on a gold mine tailings dump. A recent soil sample analysis requested by the Federation for a Sustainable Environment showed elevated levels of aluminium, arsenic, cadmium, cobalt, copper, mercury, manganese, nickel, zinc and uranium. An independent international expert in 2011 
found radiation levels 15 times higher than the regulated level. He advised on the immediate relocation of the community. The National Nuclear Regulator of South Africa confirmed the grounds were indeed radioactive and Parliament recommended relocation of the community in 2011. The majority of them are still living here. No health outcome studies related to the exposure of the community to high levels of radiation is as yet available.

Here is what community members had to say:

We have been living here for up to 10 years. Our children are sick from birth with flu and chest problems. I have to take my 9 month old son to the clinic almost every week with a runny nose and cough. The water is not good and there is only 4 taps for all of us. Children commonly have vomiting and diarrhoea.

Toilets are broken and never clean and too few for all of us living here. Itching of the skin is common and worse for children. TB is getting worse. The dust from the new mining on the dumps makes coughing worse. We attend the clinic but the treatment for TB is not helping anymore.

We have no electricity for cooking. Cooking with paraffin and coal is bad for the flu and dangerous for fires. In winter it is worse when it is very cold.

We have toyi-toyi'd and have attended many meetings. We get promises for new stands but we are still here. Our story have (sic) been in the newspapers. A few families have been given houses near Kagiso. This is the start of a new year and we are hopeful for new homes.

An elderly woman next to the Tudor dam explained that mining now started right next to her home. She worked for about 45 years as a domestic worker and now lives next to the mine dumps. She is suffering from high blood pressure and has very poor eyesight. She has no running water in her home and no electricity. The future is uncertain. No-one has come to talk to her about the new mining or the relocation. During the interview we heard the deafening sounds of nearby mine blasts".

\section{CASE STUDY 3. 'The legacy of gold mining activities around Johannesburg'}

\section{Excerpted from: Tutu et al., 2003 (Direct quotation).}

"The legacy of gold mining activities around Johannesburg consists of enormous heaps of tailings dumps extending over many square kilometres. These sites must be considered as potential sources of mobile uranium to the biosphere. Gamma spectrometric analysis points to significant leaching of $U$ from tailings dumps. This has caused some radioactive disequilibrium as $U$ has been decoupled from the decay series. ... Very high concentrations were obtained in water bodies in the proximity of tailings dumps whereas significant attenuation was realized in areas far from the sources. The processing of mine dumps has also contributed to enhancing acid drainage and probably oxidation of dump material, thus enhancing $U$ mobility. Wetland sediments showed that they act as traps or sinks for $U$ and other heavy metals, this being strongly demonstrated by BCR sequential extraction. The oxide-bound fractions from this protocol point to co-precipitation as the main $\mathrm{U}$ removal process from the water column. It should be noted that the toxicity of $U$ is not as a result of its radioactive nature, but rather its chemical nature. The kidney is considered the target organ for uranium's chemical toxicity. ...". 


\section{References}

Amponsah-Dacosta, M. and Reid, D.L., 2014. Mineralogical characterisation of selected South African mine tailings for the purpose of mineral carbonation. In: Sui, W., Sun, Y. and Wang., C. (Eds.): An Interdisciplinary Response to Mine Water Challenges. China University of Mining and Technology Press, Xuzhou. p. 686 - 692.

Anglo (2005). Guidelines for the Operation of Tailings Disposal Facilities: International Perspective and Explanatory Notes. Bulletin No S131/2005, Anglo American Technical Division, Johannesburg, South Africa. p. 47.

Arthur, G.D., Aremu, A.O., Kulkarni, M.G., Okem, A., Stirk, W.A., Davies, T.C. and Van Staden, J., 2015. Can the use of natural biostimulants be a potential means of phytoremediating contaminated soils from goldmines in South Africa? International Journal of Phytoremediation 18 (5), $427-434$.

Assima, G.P., Larachi, F., Molson, J. Beaudoin, G., 2013. Comparative study of five Québec ultramafic mining residues for use in direct ambient carbon dioxide mineral sequestration. Chemical Engineering Journal 245, 56 - 64.

Beaudoin, G., Constantin, H.M., Duchesne, J., Cecchi, E., Huot, F., Vigneau, S. and Fiola, R., 2008. Spontaneous carbonation of serpentine in milling and mining waste, southern Québec and Italy. ACEME08, 2nd International Conference on Accelerated Carbonation for Environmental and Materials Engineering, Rome, Italy, p. 73 - 82.

Beierle, T.C., 1999. Using social goals to evaluate public participation in environmental decisions. Review of Policy Research 16 (3 - 4), 75 - 103.

Beierle, T.C. and Konisky, D., 2001. What are we gaining from public participation? Observations from environmental planning in the Great Lakes (2001). Environment and Planning C: Government and Policy 19 (4), 515 - 527. Available at SSRN: http://ssrn.com/abstract=2708165 (accessed 30.03.16).

Bisaillon, V., Gendron, C., and Turcotte, M.F. (2005). Commerce équitable comme vecteur de développement durable? Nouvelles Pratiques Sociales 18 (1), 73 - 89.

Busacca, M, 2013. Corporate Social Responsibility in South Africa's Mining Industry: Redressing the Legacy of Apartheid. CMC Senior Theses; Paper 632. Available at: .http://scholarship.claremont.edu/cmc_theses/632 (accessed 18.12.15).

Cairncross, E., Kisting, S., Liefferink, S. and Van Wyk, D., 2013. Case Study on Extractive Industries. Report from South Africa; Prepared for the Lancet Commission on Global Governance. 16 p. Available at: http://www.thejournalist.org.za/wpcontent/uploads/2014/09/Lancet-Study-Gold-Platinum-Mines-in-SA.pdf (accessed 08.01.15).

Caldwell, J., 2010. Republic of South Africa Tailings Impoundment Regulations. Available at: http://ithinkmining.com/2010/11/15/republic-of-south-africa-tailings-impoundment-regulations/ (accessed 28.12.14). 
Campbell, B., 2012. Corporate social responsibility and development in Africa: Reducing the roles and responsibilities of public and private actors in the mining sector. Resource Policy 37 , $138-143$.

Capel, J., 2012. Are Mining Profits Ethically Earned? Business Report February 08, 2012. Available at: http:/www.iol.co.za/business/opinion/columnists/are-mining-profits-ethicallyearned-1.1229375? showComments=true\#.VK-ucSuUfms (accessed 09.01.15).

CER (Centre for Environmental Rights), 2013. Annual Report 2012-2013. Available at: http://cer.org.za/wp-content/uploads/2013/09/CER-AR-2012-13.pdf (accessed 10.05.14).

Cessford, F., 2004. New Mining Regulations: What They Mean for Water Management. Proceedings of the 2004 Water Institute of Southern Africa (WISA) Biennial Conference, 02 to 06 May, 2004, Johannesburg, South Africa. 7 p. Available at: http://www.ewisa.co.za/literature/files/060.pdf (accessed 02.01.15).

Clarkson, M.B.E., 1995. A stakeholder framework for analyzing and evaluating corporate social performance. Academy of Management Review 20 (1), 92 - 117.

Cliffe Dekker Attorneys, 2002. The King Report on corporate governance for South Africa.

Cliffe Dekker Attorneys, Johannesburg, South Africa. 24 p. Available at: www.mervynking.co.za/downloads/CD_King2.pdf (accessed 29.03.16).

Cronje, F., Reyneke, S., and van Wyk, D., 2013. Journal of Disaster and Risk Studies 5 (2). Local communities and health disaster management in the mining sector. Art. \#78, 12 pages.Available at: http://jamba.org.za/index.php/jamba/article/view/78/170 (accessed 13.07.14).

Cullinan, C., 2015. Stringent new legislation for SA mine dumps and stockpiles. Available at: http://www.miningreview.com/features/stringent-new-legislation-for-sa-mine-dumps-andstockpiles/ (accessed 26.03.16).

Davies, M.P., 2001. Impounded mine tailings: What are the failures telling us? Distinguished Lecturer Series, Canadian Institution of Mining. Available at: www.infomine.com/library/publications/docs/Davies2001.pdf (accessed 28.03.16).

Davies, T.C. and Mundalamo, H.R., 2010. Environmental health impacts of dispersed mineralisation in South Africa. Journal of African Earth Sciences 58 (4), 652 - 666.

DBSA (Development Bank of Southern Africa), 2004. Guide to Best practice in the Operation, Maintenance and Safety of Dams. Phakisa Communications, Randburg, South Africa. 20 p. Available at: www.dbsa.org/EN/About-Us/.../Best\%20Practise\%20Dams.pdf (accessed 29.03.16).

Diale, A.J., 2014. Corporate social responsibility in the South African mining industry: Necessity, conformity or convenience? International Journal of Business and Economic Development 2 (1), 16 - 26.

Engelbrecht, L., 2009. Draft Code of Governance Principles for South Africa - 2009. The King Committee on Governance. Parklands, South Africa. 141 p. 
Eweje, G., 2005. Hazardous employment and regulatory regimes in the South African mining industry: Arguments for corporate ethics at workplace. Journal of Business Ethics 56, 163 - 183.

Feris, J., 2013. Mine dumps in South Africa: An ownership dilemma. Available at: http://www.environment.co.za/mining-2/mine-dumps-south-africa-ownership-dilemma.html. (accessed 26.03.16).

Feris, L. and Kotzé, L.J., 2014. The regulation of acid mine drainage in South Africa: law and governance perspectives. PER vol.17 n.5. Available at: http://dx.doi.org/10.4314/pelj.v17i5.07 (acccessed 19.08.2017).

Flores-Araoz, F., 2011. Corporate social responsibility in South Africa: More than a nice situation. Available at: http://www.consultancyafrica.com/index.php?option $=$ com_content\&view $=$ article\&id $=835$ :corpor ate-social-responsibility-in-south-africa-more-than-a-nice-intention\&catid=82:african-industry-abusiness\&Itemid=266 (accessed 04.01.15).

Fooks, G., Gilmore, A., Collin, J., Holden, C. and Lee, K., 2013. The limits of corporate social responsibility: Techniques of neutralisation, stakeholder management and political CSR. Journal of Business Ethics 112, 283 - 299.

Goldblatt, M., Gelb, S. and Davies, G., 2002. Macroeconomics and sustainable development in Southern Africa; Synthesis Report of South African study. Development Bank of South Africa. Midrand, South Africa. 88 p.

Goodland, R. 2012. Responsible Mining: The Key to Profitable Resource Development. Institute for Environmental Diplomacy and Security (IEDS), Vermont, USA. 32 p. Available: http://www.uvm.edu/ieds/sites/default/files/Responsible_Mining.pdf (accessed 17.08.12).

Gore, S. and and Erasmus, T-E., 2015. New onerous regulation and financial implications for residue stockpiles and deposits. Available at: https:/www.cliffedekkerhofmeyr.com/en/news/publications/2015/environmental/environmentalalert-24-august-new-onerous-regulation-and-financial-implications-for-residue-stockpiles-anddeposits-.html (accessed 27.03.16).

Grunwald, A., 2015. The imperative of sustainable development: In: Wyss, M. and Peppoloni, S. (Eds.). Geoethics: Ethical Challenges and Case Studies in Earth Sciences. Elsevier Publishers, Amsterdam, the Netherlands. p. $26-36$.

Hart, R. and Coumans, C., 2014. Evolving standards and expectations for responsible mining: A civil society perspective. In: Irina, N. \& Stückelberger, C. (Eds.), Mning Ethics and Sustainability. Papers from the World Mining Congress, 2013. Globethics.net Global 8. Ganeva; p. 4161.6 Available at: http://www.globethics.net/documents/4289936/13403236/GE_Global_8+_Mining_ethics_web_fi nal.pdf/7974f77b-0b67-4155-b75c-418d670abc27 (ccessed 31.08.15).

Hydralok, 2016. Top Five Mining Countries in the World and Their GDP. Available at: https://www.hydralok.net/top-five-mining-countries-in-the-world-and-their-gdp/ (accessed 31.03.16). 
IPCC (Intergovernmental Panel on Climate Change), 2008. Climate Change 2007; Synthesis Report. WHO/UNEP, Geneva, Switzerland. 112 p. Available at: https://www.ipcc.ch/pdf/assessment-report/ar4/syr/ar4_syr_full_report.pdf (accessed 30.03.16).

Irina, N. and Stückelberger, C., 2014. Mining ethics and sustainability: Papers from the World Mining Congress. Globethics.net Global 8. Geneva. 198 pp. Available at:

http://www.globethics.net/documents/4289936/13403236/GE_Global_8+_Mining_ethics_web_fi nal.pdf/7974f77b-0b67-4155-b75c-418d670abc27 (accessed 26.12.14).

Kilani, J., 1998. The Codes of Practice for Mine Residue Deposits. Workshop on Risk Management and Contingency Planning in the Management of Mine Tailings; 5 - 6 November, 1998, Buenos Aires, Argentina. International Council on Metals and the Environment (ICME), United Nations Environment Programme (UNEP); p. 295 - 298.

Kolk, A., Van Tulder, R. and Welters, C., 1999. International codes of conduct and corporate social responsibility: Can transnational corporations regulate themselves? Transnational Corporations $\quad 8 \quad(1), \quad 143 \quad-\quad 180 . \quad$ Available at: http://unctad.org/en/Docs/iteiit12v8n1_en.pdf\#page=151 (accessed 08.01.15).

Lake, J., 2017. Regulations Regarding the Planning and Managemnent of of Residue Stockpiles and Residue Deposits. SRK Consulting. Available at: http://www.srk.com/sites/default/files/file/JLake_RegulationsOfResidueStockpiles_2017.pdf (accessed 18 August 2017).

Lèbre, E. and Corder, G., 2015. Integrating industrial ecology thinking into the management of mining waste. Resources 4, 765 -786; doi:10.3390/resources4040765.

Liefferink, M., 2011. Assessing the past and the present role of the 'National Nuclear Regulator' as a public protector against potential health injuries: The West and Far West Rand as case study. New Contree, No. 62, 125 - $153 . \quad$ Available at: dspace.nwu.ac.za/bitstream/handle/.../No_62(2011)_Liefferink_M.pdf?... (accessed 30.03.16).

Mabuza, L., Msezane, N. and Kwata, M., 2010. Mining and Corporate Social Responsibility Partnerships in South Africa. Africa Institute of South Africa (AISA) Policy Brief Number 15 February 2010. Available at:

http://www.ai.org.za/wp-content/uploads/downloads/2011/11/No-15.-Mining-and-CorporateSocial-Responsibility.pdf (accessed 04.01.15).

Malatse, M. and Ndlovu, S., 2015. The viability of using the Witwatersrand gold mine tailings for brickmaking. Journal of the Southern African Institute of Mining and Metallurgy 115 (4). Online version ISSN 2411-9717. Available at: http://www.scielo.org.za/scielo.php?script=sci_arttext\&pid=S0038-223X2015000400014 (accessed 01.04.16).

McDonald, D.A., 2002. What Is Environmental Justice? In: McDonald, D.A. (Ed.), Environmental Justice in South Africa. Ohio University Press, Athens/University of Cape Town, South Africa. $\quad$ p. 1 - $12 . \quad$ Available at: http://books.google.co.za/books?hl=en\&lr=\&id=F1WdPPD15pYC\&oi=fnd\&pg=PR9\&dq=Envir onmental++Justice++Mcdonald\&ots=SHfNc_5Y2V\&sig=mQ9L0PURceIU3LOw1OUi- 
BCN078\# $\mathrm{v}=$ onepage \&q=Environmental $\% 20 \% 20 \mathrm{Justice}^{2} \% 20 \% 20 \mathrm{Mcdonald} \& \mathrm{f}=$ false $\quad$ (accessed 08.01.15).

Mcguire, G., 2003. Environmental Impacts of Mining on Women in Indonesia and northern Australia. www.mcguireenvironmentalimpacts.pdf (accessed21.03.16).

Mannak, M., 2012. South Africa: Mines Threaten the Environment. http://www.ethicalliving.co.za/south-africa-mines-threaten-the-environment/ (accessed 21.12.14).

Manungufala, T.E., Sabiti-Kalule, M. and Aucamp, I., 2005. Investigation into the slimes dams, mine dumps and landfills (residue deposits) as environmental constraints to low-cost housing projects in Gauteng, South Africa. XXIII IAHS World Congress on Housing: Transforming Housing Environments through Design. September 27-30, 2005, Pretoria, South Africa, 7 p. Available at: http://repository.up.ac.za/bitstream/handle/2263/10365/Investigation\%20into\%20the\%20slimes $\% 20$ dams $\% 20$ mine $\% 20$ dumps $\% 20$ and\%20landfills.pdf?sequence=1(accessed 28.12.14).

Mariri, T. and Chipunza, C., 2011. Corporate governance, corporate social responsibility and sustainability: Comparing corporate priorities within the South African mining industry. Journal of Human Ecology 35 (2), 95 - 111.

Martin, T.E., M.P. Davies, M.P., Rice, S., Higgs, T and Lighthall, P.C., 2002.

Stewardship of Tailings Facilities. Report No. 20 of the Mining, Minerals and

Sustainable Development (MMSD) Project of the International Institute of Environment and Development (IIED) and the World Business Council for Sustainable Development (WBCSD), BC, Vancouver, Canada. 37 p. Available at: http://www.pebblescience.org/pdfs/Martin_et_al._2002_Stewardship_of_Tailings_facilities.pdf (accessed 01.01.15).

McGuire, G., 2003. Environmental impacts of mining on women in Indonesia and northern Australia. Women in Mining Conference, Madang, Indonesia, August 03 - 06, 2003. Available at: siteresources.worldbank.org/.../mcguireenvironmentalimpacts.pdf (accessed 30.03.16).

Meintjes, A., 2014. Benefits of dry tailings disposal; In: Bentel, B. and Luppnow, D. (Eds.), Focus on Tailings - Operational Tailings Management for Successful Closure. SRK International Newsletter No. 29. Available at: http://www.srk.co.za/files/File/newsletters/SRKnews29tailings_A4.pdf(accessed 30.03.16).

Mesjasz-przybyłowicz, J., nakonieczny, M., Migula, P., Augustyniak, M., Tarnawska, M., Reimold, W.U., Koeberl, C., Przybyłowicz, and Głowacka, E., 2004. Uptake of cadmium, lead, nickel and zinc from soil and water solutions by the nickel hyperaccumulator berkheya coddii. Acta Biologica Cracoviensia Series Botanica 46, 75 - 85.

Mukheibir, P. and Sparks, D., 2003. Water resource management and climate change in South Africa: Visions, driving factors and sustainable development indicators. Report for Phase I of the Sustainable Development and Climate Change Project; Energy and Development Research Centre, University of Cape Town. 19 p.

Porter, M.E. and Kramer, M.R., 2006. Strategy and society: The link between_competitive advantage and corporate social responsibility. Harvard Business Review 84 (12), 78 - 92. 
Rademeyer, B., 2007. The Influence of Environmental Impacts on Tailings Impoundment Design. $\mathrm{PhD}$ Thesis, University of Pretoria. 328 p. Available at: http://upetd.up.ac.za/thesis/available/etd-01292008-172436/unrestricted/00front.pdf (accessed 04.01.15).

Reichardt, M., 2012. A history of mine waste rehabilitation techniques in South Africa: A multidisciplinary overview of mine waste rehabilitation and the nonscientific drivers for its implementation 1950s - 1980s. University of Witwatersrand. Available at: http://www.imhc.co.za/assets/pdf/papers/Konferenz\%20Papier-Reichardt.pdf （accessed 23.02.16).

Robinson, R.E., 2010. Susainability and slimes dams. The Southern African Institute of Mining and Metallurgy. Available at:

http://www.saimm.co.za/journal-comments/137-sustainability-and-slimes-dams (accessed 02.01.16).

Roodt, N.J., Van Der Want, M., and Picas, C., 2012. Mine dumps under the amended Mineral and Petroleum Resources Development Act 28 of 2002. The Journal of the Southern African Institute of Mining and Metallurgy 110, 469 - 472.

RSA DEA (Republic of South Africa Department of Environmental Affairs ), 2009. The National Environmental Management Act (Act No 107 of1998). The Government Printer, Johannesburg.https://www.westerncape.gov.za/other/2009/12/nema_02.12.2009.pdf (accessed 01.01.16).

RSA DEA (Republic of South Africa Department of Environmental Affairs), 2010. National Waste Management Strategy. First Draft for Public Comment. Department of Environmental Affairs, Pretoria. 155 p. Available at: http//www.First_Draft_National_Waste_Management_Strategy_as_published_by_DEA(2).pdf (accessed 19.03.16).

RSA DEA (Republic of South Africa Department of Environmental Affairs), 2012. 2012 South Africa Environment Outlook', Chapter 9: Waste Management, Draft 2. Pretoria, South Africa. 31 p. Available at:

http://soer.deat.gov.za/dm_documents/2012_SAEO_Waste_Management_Draft2_IleRc.pdf (accessed 10.01.15).

RSA DME (Republic of South Africa Department of Minerals and Energy), 2000. Guideline for the Compilation of a Mandatory Code of Practice on Mine Residue Deposits, Pretoria, South Africa. 23 p. Available at: www.tailings.info/knowledge/guidelines.htm (accessed 31.03.16).

RSA DME (Republic of South Africa Department of Minerals and Energy), 2001. Publication of Environmental Management Plan Under Section 15 (2) (b) of the National Environmental Management Act, 1998 (Act No. 107 of 1998). Pretoria, South Africa. 78 p. Available at: www.enviroleg.co.za/acts/.../REGS/435-01\%20minerals.pdf (accessed 30.03.16).

RSA DME (Republic of South Africa Department of Minerals and Energy), 2005. Radioactive Waste Management Policy and Strategy for the Republic of South Africa. Department of Minerals and Energy, Pretoria. 33 p. Available at: http//www.radiowaste_policy_2005_0.pdf (accessed 19.03.16). 
RSA DMR (Republic of South Africa Department of Mineral Resources), 2010. Amendment of the Broad-Based Socio-economic Empowerment Charter for the South African Mining and Minerals Industry. Pretoria, South Africa. 20 p. Available at: www.gov.za/sites/www.gov.za/files/33573_838.pdf(accessed 30.03.16).

RSA DWAF (Republic of South Africa Department of Water Affairs and Forestry), 2007. Best Practice Guidelines for Water Resource Protection in the South African Mining Industry. Available at: https://commondatastorage.googleapis.com/comsa/Best\%20Practice\%20Guidlines\%20\%20A4_Pollution\%20Control\%20Dams.pdf (accessed 01.02.16).

RSA GPW (Republic of South Africa Government Printing Works), 2015. Government Gazette (Staatskoerant) Vol. 601, No. 3902. Pretoria, South Africa. 20 p. Available at: sawic.environment.gov.za/documents/4452.pdf (accessed 30.03.16).

RSA MWA (Republic of South Africa Ministry of Water Affairs), 1986. Regulations in Terms of Section 9c(6) of the Water Act, 1956, Relating to Dams With a Safety Risk; Doc. No. R.1560. Pretoria, South Africa. 35 p. Available at: https://www.dwa.gov.za/dso/documents/notice156025jul86.pdf (accessed 29.03.16).

RSA OP (Republic of South Africa Office of the President), 1965. Atmospheric Air Pollution Prevention Act 45 of $1965 . \quad$ Available at: http://soer.deat.gov.za/dm_documents/Act_Atmospheric_Pollution_Prevention_Act__45_of_1965_O4ZGw.pdf (accessed 02.01.16).

RSA OP (Republic of South Africa Office of the President), 1991. The Minerals Act No. 50 of 1991. http://soer.deat.gov.za/dm_documents/Minerals-Act-50-of-1991_zJ7qk.pdf (accessed 01.01.16).

RSA OP (Republic of South Africa Office of the President), 1996a. Constitution of the Republic of South Africa No. 108 of 1996. Available at: :http://www.gov.za/sites/www.gov.za/files/images/a108-96.pdf (accessed 02.01.16).

RSA OP (Republic of South Africa Office of the President), 1996b. Mine Health and Safety Act No. 29 of 1996. Available at: http://www.kznhealth.gov.za/occhealth/17242.pdf (accessed 02.01.16).

RSA OP (Republic of South Africa Office of the Presidency), 1999. The National Amendment Act, No. 45 of 1999. Available at:

http://pmg-assets.s3-website-eu-west-1.amazonaws.com/docs/081022wateract.pdf (accessed 01.01.16).

RSA OP (Republic of South Africa Office of the President), 2002. The Mineral and Petroleum Resources Development Act 28 of 2002. Available at: https://www.capetown.gov.za/en/EnvironmentalResourceManagement/publications/Documents/ Minerals-and-Petroleum-Resources-Development-Act-28-of-2002.pdf (accessed 02.01.16).

RSA OP (Republic of South Africa Office of the President), 2005. National Environment Management: Air Quality Act No. 39 of 2004. Available at: https://www.environment.gov.za/sites/default/files/legislations/nema_amendment_act39.pdf (accessed 02.01.16). 
SABS (South African Bureau of Standards), 1998. SABS 0286:1998: Code of Practice - Mine Residue Deposits; SABS 0286:1998 (ICS 73.020). South African Bureau of Standards. 117 p. Available at: http://docslide.us/documents/sans-10286.html (accessed 31.03.16).

SAICA, (South African Institute of Chartered Accountants), 2013. King III: Code, Principles and Practices (Summary). SAICA, Johannesburg, South Africa. 16 p. Available at: https://www.saica.co.za/Technical/LegalandGovernance/King/tabid/2938/language/en-ZA (accessed 29.03.16).

Sangonet, 2013. Sustainable CSR and Mining in South Africa. Available at: http://www.ngopulse.org/article/sustainable-csr-and-mining-south-africa (accessed 04.05.15).

SANS (South African National Standards), 1998. SANS 10286, Code of Practice for Mine Residue Deposits. Available at: http://www.tailings.info/knowledge/guidelines.htm (accessed 22.03.16).

Saperstein, L., 2014. Ethics in the mining industry. Society for Mining, Metallurgy and Exploration. Englewood Cliffs, CO. Available at:

http://www.smenet.org/store/mining-books.cfm/Ethics-in-the-Mining-Industry/STO-ETHICS (accessed 03.01.15).

Schonfeld, S.J., Winde, F., Albrecht, C., Kielkowski, D., Liefferink, M., Patel, M., Sewram, V., Stoch, L., Whitaker, C., Schüz, J. and Workshop Participants, 2014. Health effects in populations living around the uraniferous gold mine tailings in South Africa: Gaps and opportunities for research. Cancer Epidemiology 38 (5), 628 - 32.

Sharma., P. and Pandey, S., 2014. Status of phytoremediation in world scenario. International Journal of Environmental Bioremediation and Biodegradation 2 (4): 178 - 191.

Snyman, B.J. and Brent, A.C., 2006. Aligning environmental and regulatory procedures with a holistic project management approach for residue deposits: Mine Waste Disposal and Achievement of Mine Closure - What Does It Take? The South African Institute of Mining and Metallurgy. Johannesburg, South Africa. 20 p. Available at: http://repository.up.ac.za/bitstream/handle/2263/4113/SnymanBrentSAIMM2006.pdf?sequence= 1 (accessed 02.01.15).

Sutton, M.W. and Weiersbye, I.M., 2007. South African legislation pertinent to gold mine closure and residual risk. In: Fourie, A., Tibbett, M. and Wiertz, J. (Eds.), Mine Closure 2007, Proceedings of the Conference in Santiago, Chile, 2007. Published by the Australian Centre for Geomechanics, Perth, Australia. Available at: http://mobile.wiredspace.wits.ac.za/bitstream/handle/10539/12692/Appendix\%20II\%20Sutton_a nd_Weiersbye_2007.pdf?sequence=2 (accessed 09.01.15).

Swart, E. 2003. The South African legislative framework for mine closure. Journal of the South African Institute of Mining and Metallurgy 103 (8), 489 - 492.

Tutu, H., Cukrowska, E., McCarthy, T.S., Mphephu, N.F. and Hart, R., 2003. Determination and modelling of geochemical speciation of uranium in gold mine polluted land in South Africa. Proceedings of the 8th International Mine Water and the Environment Congress, Johannesburg, South Africa. Available at: https://www.imwa.info/docs/imwa_2003/imwa_2003_137-155.pdf (accessed 16.03.16). 
Van Eeden, E.S., Liefferink, M. and Durand, J.F., 2009. Legal issues concerning mine closure and social responsibility on the West Rand. The Journal for Transdisciplinary Research in Southern Africa 5 (1), 51 - 71.

Van Niekerk, H.J. and Viljoen, M.J., 2005. Causes and consequences of the Merriespruit and other tailings-dam failures. Land Degradation and Development (Special Issue) 16 (2), 201 - 212.

Vermeulen, N.J., 2001. The Composition and State of Gold Tailings. PhD. Thesis,

University of Pretoria, Pretoria. Available at: repository.up.ac.za/bitstream/handle/2263/23079/00front.pdf?...1(accessed 31.03.16).

World Bank, 2016. Global Economic Prospects, Chapter 2: Sub-Saharan Africa. A World Bank Flagship Report. International Bank for Reconstruction and Development / The World Bank, Washington DC, USA. p. 153 - 176. Available at: Global-Economic-Prospects-January-2016Sub-Saharan-Africa-Analysis(1)pdf (accessed 31.03.16).

WNA (World Nuclear Association), 2006. Safe Decommissioning of Civil Nuclear Industry Sites. Available at: http://world-nuclear.org/our-association/publications/positionstatements/safe-decommissioning-of-civil-nuclear-industry-sit.aspx (accessed 19.03.16).

Wright, C.Y., Matooane, M., Oosthuizen, M.A. and Phala, N., 2014. Risk perceptions of dust and its impacts among communities living in a mining area of the Witwatersrand, South Africa. Clean Air Journal 24 (1), 22 - 27. 